\title{
Reactions of Anilines and Benzamides with a Fourteen-Electron Iridium(I) Bis(Phosphinite) Complex: N-H Oxidative Addition versus Lewis Base Coordination
}

\author{
Alison Cartwright Sykes, Peter White, and Maurice Brookhart \\ Department of Chemistry, University of North Carolina at Chapel Hill, Chapel Hill, North Carolina, \\ 27599-3290
}

\begin{abstract}
Anilines react with $(\mathrm{POCOP}) \operatorname{Ir}\left(\mathrm{C}_{6} \mathrm{H}_{5}\right)(\mathrm{H}), \mathbf{1 2},\left(\mathrm{POCOP}=2,6-\left(\mathrm{OP} t \mathrm{Bu}_{2}\right)_{2} \mathrm{C}_{6} \mathrm{H}_{3}\right)$ to yield equilibrium mixtures of 12, the $\operatorname{Ir}(\mathrm{I}) \sigma$-complexes (POCOP) $\operatorname{Ir}\left(\mathrm{NH}_{2} \mathrm{Ar}\right.$ ), 13, and the $\operatorname{Ir}(\mathrm{III})$ oxidative addition adducts (POCOP) $\operatorname{Ir}(\mathrm{H})(\mathrm{NHAr}), 14$. Quantitative studies of these equilibria for a series of anilines were carried out. Anilines possessing electron-withdrawing groups favor the $\operatorname{Ir}(\mathrm{III})$ oxidative addition adduct over the $\operatorname{Ir}(\mathrm{I})$ sigma complex. Low temperature studies using $p$-chloroaniline show that the $\operatorname{Ir}(\mathrm{I}) \sigma$-complex is the kinetic product of reaction and is likely the precursor to the $\operatorname{Ir}(\mathrm{III})$ oxidative addition adduct. Reductive elimination of complexes 14 in the presence of ethylene led to the corresponding anilines and the ethylene complex (POCOP) $\operatorname{Ir}\left(\mathrm{C}_{2} \mathrm{H}_{4}\right)$. Kinetic analysis of these reactions for 14e,f,g bearing electron-withdrawing aryl groups $\left(\mathrm{Ar}-=p-\mathrm{CF}_{3} \mathrm{C}_{6} \mathrm{H}_{4^{-}}, \mathrm{C}_{6} \mathrm{~F}_{5^{-}}, 3,5\right.$-bis $\left.\left(\mathrm{CF}_{3}\right) \mathrm{C}_{6} \mathrm{H}_{3}-\right)$ shows the rate is independent of ethylene concentration. The $\Delta \mathrm{G}^{\ddagger}$ values for these reductive eliminations fall in the range of $21-22 \mathrm{kcal} / \mathrm{mol}$. X-Ray analysis establishes $14 \mathrm{f}(\mathrm{Ar}-=$ $\mathrm{C}_{6} \mathrm{~F}_{5^{-}}$) as a square pyramidal complex with the hydride occupying the apical site. Reaction of $\mathbf{1 2}$ with benzamides 21a,b yields quantitatively the $\operatorname{Ir}(\mathrm{III})$ oxidative addition adducts, (POCOP) $\operatorname{Ir}(\mathrm{H})$ $(\mathrm{NHC}(\mathrm{O}) \mathrm{Ar}), 22$. X-Ray analysis of 22b $\left(\mathrm{Ar}-{ }^{-} \mathrm{C}_{6} \mathrm{~F}_{5^{-}}\right)$shows significant interaction of the carbonyl oxygen with Ir in the site trans to hydride. The barrier to reductive elimination of 22a, $29 \mathrm{kcal} / \mathrm{mol}$, is substantially higher than for complexes $\mathbf{1 4 e , f , g .}$
\end{abstract}

\section{Keywords}

N-H Activation; Oxidative Addition; Reductive Elimination; Iridium Pincer Complexes; Electronic Effects

\section{Introduction}

Carbon-hydrogen bond activation by late transition metal complexes has received intense scrutiny over the past two decades since the classic work of Bergman ${ }^{1}$, Jones ${ }^{2}$, and Graham $^{3}$. Fundamental studies including kinetics, thermodynamics, and selectivities of the oxidative addition reactions of $\mathrm{C}-\mathrm{H}$ bonds to a variety of transition metal centers together with theoretical investigations have appeared. ${ }^{4,5}$ More recently, these reactions have been incorporated into catalytic cycles, and there are now numerous useful catalytic organic transformations based on $\mathrm{C}-\mathrm{H}$ bond activation reactions. ${ }^{6-12}$ 
Although $\mathrm{N}-\mathrm{H}$ and $\mathrm{C}-\mathrm{H}$ bonds exhibit similar homolytic bond strengths, many fewer investigations of late metal activation of $\mathrm{N}-\mathrm{H}$ bonds have been carried out. ${ }^{13-16}$ Such studies could impact the rapidly growing number of metal-catalyzed transformations of amine and related compounds including hydroaminations of alkenes, styrenes, dienes, and alkynes. ${ }^{17-}$ 20 Some of these transformations appear to involve oxidative addition of $\mathrm{N}-\mathrm{H}$ bonds, ${ }^{21,22}$ while the mechanisms of many other transformations are unknown, but some could involve an $\mathrm{N}-\mathrm{H}$ oxidative addition step.

An early instructive example of oxidative addition of N-H bonds to late transition metal centers was reported by Merola who showed that the $\mathrm{N}-\mathrm{H}$ bonds of pyrroles and indoles oxidatively add to the $\operatorname{Ir}(\mathrm{I})$ moiety, $(\mathrm{COD})\left(\mathrm{PMe}_{3}\right)_{3} \mathrm{Ir}^{+}$, to yield the eighteen-electron, octahedral $\mathrm{Ir}(\mathrm{III})$ species as illustrated in equation $1 .{ }^{23}$

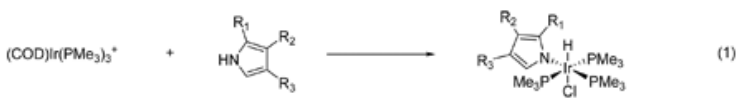

The Goldman, Jensen, and Kaska groups have shown that the 14-electrSon complex (PCP)Ir $\left(\mathrm{PCP}=2,6-\left(\mathrm{CH}_{2} \mathrm{P} t \mathrm{Bu}_{2}\right)_{2} \mathrm{C}_{6} \mathrm{H}_{3}\right), \mathbf{1}$, generated from treatment of the dihydride $(\mathrm{PCP}) \operatorname{Ir}(\mathrm{H})_{2}$ with acceptors such as tert-butylethylene, readily oxidatively adds $\mathrm{C}-\mathrm{H}$ bonds of alkanes and arenes. 24,25 Such species are highly active for catalytic transfer dehydrogenation of alkanes and can also be used for synthesis of enamines through transfer dehydrogenation of tertiary amines.

26 Goldman and Hartwig have recently observed that the (PCP)Ir complex 1 oxidatively adds the N-H bond of aniline to produce the Ir(III) anilino hydride 2 as shown in equation $2 .{ }^{27} \mathrm{In}$ benzene, adduct 2 equilibrates with the phenyl hydride complex 3 . The equilibrium favors the anilino hydride complex with a $\mathrm{K}_{\mathrm{eq}}=105$ at $22^{\circ} \mathrm{C}$ (Eq. 3).

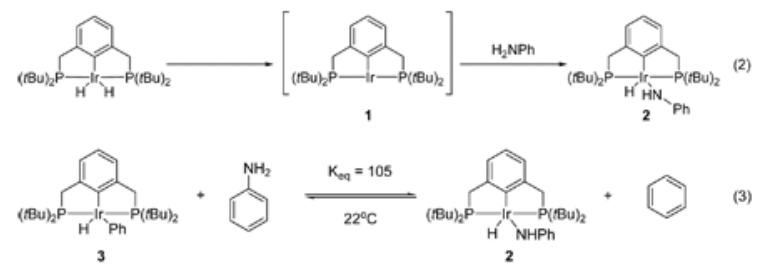

Attempted oxidative addition of the better $\sigma$-donor ammonia results in the $\operatorname{Ir}(\mathrm{I})$ ammonia complex 4 . The amido hydride 5 could be independently generated by dehydrochlorination of 6 at $-78^{\circ} \mathrm{C}$. Warming to $25^{\circ} \mathrm{C}$ resulted in conversion to ammonia complex 4 , indicating that thermodynamically the ammonia complex is favored over the amido hydride (Eq. 4). When a more electron-donating saturated backbone is incorporated in the pincer ligand, oxidative addition of ammonia occurs rather than simple coordination. ${ }^{28}$ Treatment of 7 with ammonia yields the $\operatorname{Ir}(\mathrm{III})$ amido hydride in high yields at $25^{\circ} \mathrm{C}$ (Eq. 5).

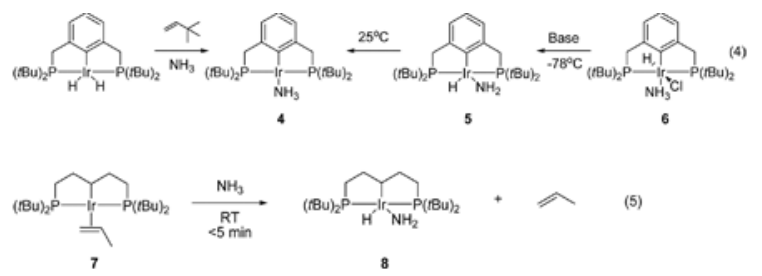

Our laboratory ${ }^{29-31}$ has investigated the chemistry of more electron-deficient Ir pincer complexes based on the bis(phosphinite) ligand, POCOP $=2,6-\left(\mathrm{OP} t \mathrm{Bu}_{2}\right)_{2} \mathrm{C}_{6} \mathrm{H}_{3}$. The highly active 14-electron complex $\mathbf{1 0}$ can be conveniently generated in situ by treatment of the hydrido chloride $\mathbf{9}$ with sodium tert-butoxide. Generation of $\mathbf{1 0}$ in a cyclooctane/tert-butylethylene 
mixture produces a highly active catalyst system for transfer dehydrogenation and production of cyclooctene and cyclooctadiene. Detailed mechanistic studies of this system have complemented the studies of Goldman on $\mathbf{1}$ and provided interesting contrasts suggesting the phosphinite POCOP system prefers the Ir(I) oxidation state relative to the PCP systems. ${ }^{29-31}$

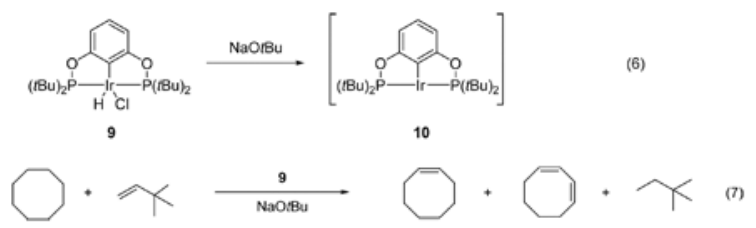

In this manuscript we report the reaction of a series of substituted anilines and benzamides with the phosphinite pincer complex 10. In the case of the anilines, either the $\operatorname{Ir}(\mathrm{III})$ oxidative addition adduct, the $\operatorname{Ir}(\mathrm{I}) \sigma$-complex, or a mix of these products is formed depending on the nature of the para-substituent. Rates of reductive elimination of the $\operatorname{Ir}(\mathrm{III})$ species have been measured, as well as the equilibria in benzene between the aniline adducts and the phenyl hydride. Information on the mechanism of reductive elimination was attained through the study of low temperature reactions of both the $p$-chloroaniline and the $p$-methoxyaniline complexes.

\section{Results and Discussion}

\section{I) Reaction of (POCOP)Ir pincer complexes with various anilines (11a-g)}

a) Equilibration of (POCOP) $\operatorname{Ir}(\mathrm{H})\left(\mathrm{C}_{6} \mathrm{H}_{5}\right)(12)$ with various $(\mathrm{POCOP}) \operatorname{Ir}\left(\mathrm{NH}_{2} \mathrm{Ar}\right)(13)$ and (POCOP)Ir(H)NHAr) (14)-The reactions of anilines shown in Chart 1 with the fourteen-electron (POCOP)Ir pincer complex 10 were carried out by treatment of the hydrochloride complex 9 with $\mathrm{NaO} t \mathrm{Bu}$ and anilines 11a-g in benzene at room temperature for 1.5 hours. The phenyl hydride complex $\mathbf{1 2}$ is in rapid equilibrium with $\mathbf{1 0},{ }^{31}$ and thus reacts with the aniline to form either the $\sigma$-complex 13 or the oxidative addition adduct 14 . The three species, 12, 13, and $\mathbf{1 4}$ depicted in Scheme 1 are all in equilibrium at $25{ }^{\circ} \mathrm{C} .{ }^{31} \mathrm{P}$ NMR spectroscopy was used to determine the ratios of the three species. Complex 12 exhibits a ${ }^{31} \mathrm{P}$ shift at $182 \mathrm{ppm}^{31}$ while the $\operatorname{Ir}(\mathrm{I})$ sigma complexes show resonances in the 173.4-173.6 ppm range and ${ }^{31} \mathrm{P}$ signals of the $\operatorname{Ir}(\mathrm{III})$ oxidative addition adducts occur in the $171.7-173.3 \mathrm{ppm}$ range. The ${ }^{1} \mathrm{H}$ NMR data, as well as a crystal structure of $\mathbf{1 4 f}$ (see below), confirm the structural assignments of these species. The $\sigma$-complexes exhibit a broad $2 \mathrm{H}$ resonance around $5.2 \mathrm{ppm}$, distinct from the $\mathrm{ArNH}_{2}$ resonance for free anilines, indicating these species are exchanging slowly on the NMR time scale. The ArNHIr ${ }^{1} \mathrm{H}$ signals for the oxidative addition adducts appear in the 3.0-5.6 ppm range and are paired with a Ir-H triplet $\left(J_{P H}=12.6-13.5 \mathrm{~Hz}\right)$ at high fields ( -34.1 to $-42.2 \mathrm{ppm}$ range). The Ir hydride signal for 12 cannot be detected at room temperature due to rapid exchange with benzene via complex 10. ${ }^{31}$

The equilibrium constants, $\mathrm{K}_{1}, \mathrm{~K}_{2}$ and $\mathrm{K}_{3}$ measured by ${ }^{31} \mathrm{P}$ NMR spectroscopy at $25^{\circ} \mathrm{C}$ are summarized in Table 1. For the electron-rich $p$-methoxyaniline 11a, only the $\operatorname{Ir}(\mathrm{I}) \delta$-adduct 13a can be observed. As the substituents become more electron-withdrawing, the Ir(III) oxidative addition adduct becomes increasingly favored. For example, a 1:1 ratio of Ir(III):Ir (I) is now observed for $p$-chloroaniline 11d. For even less electron-rich anilines 11e-g, the Ir (I) species can no longer be spectroscopically detected and $\mathrm{K}_{2}$ cannot be measured. The equilibrium constants $\mathrm{K}_{3}$ between the aryl hydride and $\mathrm{Ir}(\mathrm{III})$ complexes can still be determined since benzene is in large excess relative to aniline and $\mathbf{1 2}$ can be detected. The reasons for the trends in these substituent effects will be discussed below.

To confirm the structures of the anilino hydrides, a single crystal X-ray diffraction analysis of a crystal of $\mathbf{1 4 f}$ grown from pentane at $-35^{\circ} \mathrm{C}$ was carried out. An ORTEP diagram of the 
structure, including key bond distances and angles, is shown in Figure 1. The complex is square pyramidal with the hydride in an apical position. There is an empty coordination site trans to the hydride. The dihedral angle $\operatorname{Ir}(1)-\mathrm{N}(1)-\mathrm{C}(2)-\mathrm{C}(7)$ is $32.5^{\circ}$ indicating the arene ring sits approximately perpendicular to the square plane and the filled $p$-orbital on nitrogen lies parallel to the square plane. The $\mathrm{N}-\mathrm{H}$ bond lies anti to the $\mathrm{Ir}-\mathrm{H}$ bond $(\mathrm{H}-\mathrm{Ir}(1)-\mathrm{N}(1)-\mathrm{H}$ dihedral angle = $177.3^{\circ}$ ), and thus there can be no N-H--H-Ir interaction as seen in related systems. ${ }^{32}$

It is worth noting that the crystal structure of $\mathbf{1 4 f}$ is representative of the (POCOP) $\operatorname{Ir}(\mathrm{III})$ complexes of the electron-withdrawing anilines $14 \mathbf{e}-\mathbf{g}$. The ${ }^{1} \mathrm{H}$ resonance of the hydride in these complexes falls between -41 and $-43 \mathrm{ppm}$, which seems to be characteristic of hydride shifts in these (POCOP)Ir pincer complexes when there is an empty coordination site transto the hydride. However, for the (POCOP)Ir(III) complexes of the less electron-withdrawing anilines 14b-d the chemical shift for the hydride falls between -33.3 and $-35.9 \mathrm{ppm}$. This surprisingly downfield chemical shift might be indicative of a change in orientation of the aniline substituent, where the hydride and the $N$-hydrogen are cis to each other with a possible hydrogen bonding interaction. ${ }^{32} \mathrm{~A}$ corresponding shift in the $\mathrm{ArNH}$ signal occurs moving from ca. 3.0-4.4 ppm in the adducts involving electron-withdrawing anilines $(\mathbf{1 4 e - g})$ to 5.6 ppm for $p$-chloroaniline adduct $\mathbf{1 4 d}$.

By comparing the equilibrium data for reaction with aniline with those of Goldman and Hartwig 27 , it is clear that the more electron-withdrawing (POCOP) phosphinite Ir system more strongly prefers the $\operatorname{Ir}(\mathrm{I})$ oxidation state relative to the (PCP)Ir system. At room temperature, the reaction of 1 with $\mathrm{H}_{2} \mathrm{NC}_{6} \mathrm{H}_{5}$ favors the oxidative addition product and forms only the $\mathrm{Ir}$ (III) anilino hydride complex. In benzene solution, an equilibrium is established between (PCP) $\operatorname{Ir}(\mathrm{H})\left(\mathrm{NHC}_{6} \mathrm{H}_{5}\right)$ and $(\mathrm{PCP}) \operatorname{Ir}(\mathrm{H})\left(\mathrm{C}_{6} \mathrm{H}_{5}\right)$ with a $\mathrm{K}_{\mathrm{eq}}$ of 105 favoring the formation of the iridium anilino complex. ${ }^{27}$ In the POCOP system, reaction of $\mathbf{1 0}$ with $\mathrm{NH}_{2} \mathrm{C}_{6} \mathrm{H}_{5}$ favors the $\operatorname{Ir}(\mathrm{I}) \sigma-$ complex with an equilibrium ratio of $\operatorname{Ir}(\mathrm{I}): \operatorname{Ir}(\mathrm{III})$ complexes of ca. 10:1 (See Scheme 2). These results are also supported by IR data. Comparison of the IR stretching frequency of coordinated carbon monoxide in (POCOP) $\operatorname{Ir}(\mathrm{CO})(\mathbf{1 5})\left(v_{\mathrm{co}}=1949 \mathrm{~cm}^{-1}\right)^{31}$ and (PCP) $\operatorname{Ir}(\mathrm{CO})(\mathbf{1 6})\left(\mathrm{v}_{\mathrm{co}}=\right.$ $\left.1927.7 \mathrm{~cm}^{-1}\right)^{33}$ shows a higher frequency $\mathrm{C} \equiv \mathrm{O}$ stretch for $\mathbf{1 5}$ than for $\mathbf{1 6}$, indicating that the more electron-withdrawing ligand leads to a more electron-deficient metal center.

The increasing donor ability of the lone pair of electrons on the aniline is reflected, as expected, by the increasing stability of the $\operatorname{Ir}(\mathrm{I}) \sigma$-aniline complexes relative to the $\operatorname{Ir}(\mathrm{III})$ phenyl hydride complex (compare $\mathrm{K}_{1}$ values, Table 1 ). The stability of the $\mathrm{Ir}(\mathrm{III})$ anilino hydride complexes relative to the $\mathrm{Ir}(\mathrm{III})$ phenyl hydride increases as the arene ring of the aniline becomes more electron-withdrawing ( $\mathrm{K}_{3}$ values). This behavior can be rationalized in two ways. In the $\mathrm{d}^{6}-\mathrm{Ir}$ (III) complexes, 14, all the $d \pi$ orbitals are filled and thus there are unfavorable $p_{\pi^{-}} d_{\pi}$ interactions ${ }^{34,35}$ in 14e-g. The crystal structure of $\mathbf{1 4 f}$ shows that the Ir-N-C plane lies perpendicular to the $\operatorname{Ir}(\mathrm{III})$ square plane. As illustrated in Figure 2, there is repulsive interaction between the filled Ir $d_{x y}$ orbital and the filled N $p_{y}$ orbital. As the arene becomes more electronwithdrawing, the energy of the $p_{y}$ orbital is lowered and the destabilizing interaction is reduced. This can account for the substituent effect on relative stabilities. An alternative view is that the eletronwithdrawing-substituents stabilize the negative charge on the anilino ligand, enhancing the electrostatic interaction between the metal and the anilino group, thus strengthening the Ir$\mathrm{N}$ bond. ${ }^{36,37}$

b) Rates of oxidative addition of anilines to (POCOP) iridium pincer complexes - Low temperature ${ }^{1} \mathrm{H}$ and ${ }^{31} \mathrm{P}$ studies showed that in the case of $p$-chloroaniline (which yields a 1:1 equilibrium mixture of $\mathbf{1 3 d}$ and $\mathbf{1 4 d}$ ) the kinetic product of reaction with $\mathbf{1 0}$ is the $\sigma$ complex 13d. Generation of the tolyl hydride complexes 17 (a mixture of the meta and para isomers ${ }^{31}$ ) in toluene was achieved in the usual way by reaction of the hydrochloride complex in toluene with $\mathrm{NaO} t \mathrm{Bu}$. Treatment of this solution with excess $p$-chloroaniline (10 equivs.) 
at $-50^{\circ} \mathrm{C}$ initially yields only the $\sigma$-complex, $13 \mathbf{d}$ (Eq. 8). Slow formation of the oxidative addition product 14d is observed at this temperature. While it seems likely that the oxidative addition occurs directly from the $\sigma$-complex, we have no direct proof of this. After formation of the $\sigma$-complex 13d, the rate of oxidative addition of the $p$-chloroaniline to form $\mathbf{1 4 d}$ was measured at $-12{ }^{\circ} \mathrm{C}$ via ${ }^{1} \mathrm{H}$ low temperature NMR spectroscopy. The first-order rate constant was found to be $4.8 \times 10^{-4} \mathrm{~s}^{-1}$ with $\Delta \mathrm{G}^{\ddagger}=19.7 \mathrm{kcal} / \mathrm{mol}$.

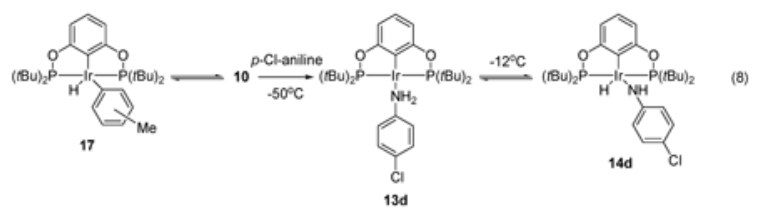

Similar low temperature experiments were conducted with 3,5-bis $\left(\mathrm{CF}_{3}\right)$ aniline 11g. At the highest achievable concentrations of aniline, a trace of a species tentatively assigned to the $\sigma$ complex $\left({ }^{31} \mathrm{P}=173.2\right.$, max concentration ca $\left.3.0 \%\right)$ could be detected as a transient during reactions carried out at $-37^{\circ} \mathrm{C}$. (Scheme 3). These results are consistent with formation of the $\sigma$-complex as the kinetic product which never builds up to significant concentrations due to rapid oxidative addition to form $\mathbf{1 4 g}$ (Path A). Again, we can not rule out direct formation of $\mathbf{1 4 g}$ from reaction of 10 with $\mathbf{1 1 g}$ (Path B).

\section{c) Rates of reductive elimination of electron-withdrawing anilines from five- coordinate (POCOP) iridium pincer complexes using ethylene as a trapping} ligand-The rates of reductive elimination of $14 \mathrm{e}, 14 \mathrm{f}$, and $14 \mathrm{~g}$ were measured by heating the $\operatorname{Ir}(\mathrm{III})$ adducts in the presence of ethylene as a trapping ligand, L, to form the iridium(I) ethylene adduct 18, as shown below in equation 9 . Complexes 14e-g were chosen for study since $\mathrm{K}_{2}$ and $\mathrm{K}_{3}$ are sufficiently large that the $\operatorname{Ir}(\mathrm{III})$ complexes can be prepared cleanly with no contamination by aryl hydride $\mathbf{1 2}$ or $\operatorname{Ir}(\mathrm{I})$ complexes. The trapping ligand must be chosen so that the 18-electron Ir(III) six-coordinate complex is not formed. A survey of several trapping ligands revealed that ethylene was ideal for this purpose $\left(\mathrm{PMe}_{3}\right.$ and carbon monoxide form the octahedral complexes $\mathbf{1 9}^{38}$ and $\mathbf{2 0}$ prior to reductive elimination, see below).

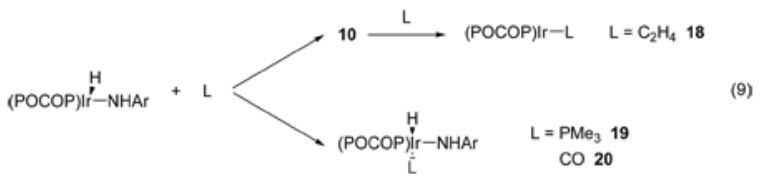

The disappearance rates of adducts $14 \mathbf{e}-\mathbf{g}$ were measured at $9{ }^{\circ} \mathrm{C}$ in the presence of excess ethylene and found to be independent of ethylene concentration (Eq. 10). Measured rate constants and free energies of activation are summarized in Table 2.
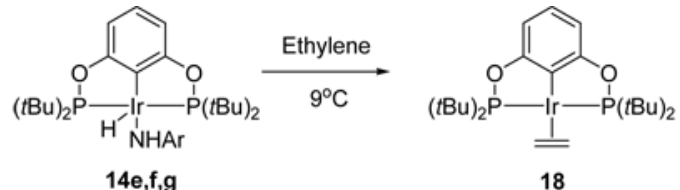

(10)

The reductive eliminations follow the same trend as the equilibrium reactions above; the more electron-withdrawing aniline reductively eliminates more slowly (Table 2). This is also evident by comparing the free energies of activation, $\Delta \mathrm{G}^{\ddagger}$ values, for the reductive eliminations. As the electron-withdrawing ability of the aniline increases, the $\Delta \mathrm{G}^{\ddagger}$ also increases from $20.8 \mathrm{kcal} /$ mol for aniline 11e to $22.1 \mathrm{kcal}$ for $\mathbf{1 1 g}$. 
In order to determine if these barriers are the true barriers for reductive elimination of anilines from 14e-g, several mechanistic scenarios, consistent with the observation that the rates of formation of ethylene complex $\mathbf{1 8}$ are independent of ethylene concentration, were considered. These are summarized in cases A-C in Scheme 4. In case A, slow reductive elimination leads directly to $\mathbf{1 0}$ followed by fast trapping by ethylene leading to formation of ethylene complex, 18. In view of the above experiments with $p$-chloroaniline which suggest the $\sigma$-complex is the precursor to oxidative addition adducts, case A seems less likely than cases in which reductive elimination initially leads to the $\sigma$-complex. In case $\mathrm{B}$, the $\sigma$-complex $\mathbf{1 3}$ is the precursor to $\mathbf{1 0}$ which is then rapidly trapped by ethylene. It is possible that the rate of formation of $\mathbf{1 3}$ is rate-determining (i.e., $\mathrm{k}_{2}>\mathrm{k}_{1}, \mathrm{k}_{-1}$ ) or that $\mathbf{1 3}$ and $\mathbf{1 4}$ are in equilibrium followed by slow formation of $10\left(k_{2}<k_{-1}\right)$. (In this latter case, the measured $\Delta G^{\ddagger}$ 's do not correspond to the true barriers for reductive elimination of $\mathbf{1 4} \mathbf{-}-\mathbf{g}$ ) In case $\mathrm{C}$, formation of $\mathbf{1 3}$ is rate-determining, followed by rapid associative displacement of the aniline by ethylene.

To probe whether displacement of anilines from $\mathbf{1 3}$ by ethylene is associative or dissociative we examined the reaction of 13a, a system for which the $\sigma$-complex 13a can be generated free of the $\operatorname{Ir}(\mathrm{III})$ oxidative addition adduct, 14a. Generation of 13a in toluene at room temperature followed by exposure to ethylene at $-8^{\circ} \mathrm{C}$ results in quantitative formation of ethylene complex 18 (Eq. 11).

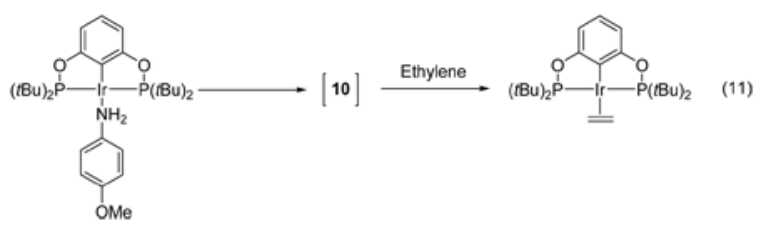

Using $0.015-0.019 \mathrm{M}$ 13a and excess ethylene concentrations of $0.25 \mathrm{M}$ and $0.48 \mathrm{M}$, clean first-order kinetics are observed at $-8^{\circ} \mathrm{C}$ with measured rate constants of $3.3 \times 10^{-4} \mathrm{~s}^{-1}$ and $2.7 \times 10^{-4} \mathrm{~s}^{-1}$, respectively. No dependence of the rate on ethylene is observed which implies that dissociation of $p$-methoxyaniline from 13a is rate-determining with a free energy of activation, $\Delta \mathrm{G}^{\dagger}$, of $19.8 \mathrm{kcal} / \mathrm{mol}$. This result rules out case $\mathrm{C}$ above and indicates case $\mathrm{B}$ as the most likely choice.

In examining case B more closely, it is instructive to consider free energy diagrams for both the $p$-chloroaniline system $\mathbf{1 3 d} / \mathbf{1 4 d}$ and $\mathbf{1 4} \mathbf{e}-\mathbf{g}$ (for simplicity consider $\mathbf{1 4 f}$ as representative of $\mathbf{1 4 e - g}$ ). (Figure 3 ) In the case of $\mathbf{1 3 d} \rightleftharpoons \mathbf{1 4 d}, \mathrm{K}_{\mathrm{eq}}=1$; therefore, barriers for reductive elimination and oxidative addition are the same, $19.7 \mathrm{kcal} / \mathrm{mol}$. Now consider $14 \mathrm{f}$. Since $14 \mathrm{f}$ is somewhat more stable than $\mathbf{1 3 f}$ one would expect the $\Delta \mathrm{G}^{\dagger}$ to be slightly greater than 19.7 $\mathrm{kcal} / \mathrm{mol}$, say $19.7+\delta$, and $\Delta \mathrm{G}^{\ddagger}-1$ to be slightly less, $19.7-\delta^{\prime}$, as shown in Figure 3. Since $\left(\mathrm{CF}_{3}\right)_{2} \mathrm{C}_{6} \mathrm{H}_{3} \mathrm{NH}_{2}$ is a poorer donor than $p$-methoxyaniline, the barrier for dissociation from (POCOP)Ir should be somewhat less than the $19.8 \mathrm{kcal} / \mathrm{mol}$ measured for 13a, designated in Figure 3 as $19.8-\delta^{\prime \prime}$. It is difficult to predict whether $\delta^{\prime}$ or $\delta^{\prime \prime}$ is larger and thus which transition state, $\mathrm{TS}_{1}$ or $\mathrm{TS}_{2}$, is higher in energy, but it is likely that the difference is quite small. The $\Delta \mathrm{G}^{\ddagger}{ }_{1}$ for $\mathbf{1 4 f}$ cannot exceed $21.1 \mathrm{kcal} / \mathrm{mol}$ (see Table 1 ) but is certainly greater than $19.7 \mathrm{kcal} /$ mol and thus is narrowly bracketed. In view of this analysis the $\Delta \mathrm{G}^{\ddagger}$ values in Table 1 likely reflect fairly accurately the barriers for reductive elimination of $\mathbf{1 4 e - g}$.

It is informative to compare the barriers of reductive elimination observed here which are in the $21-22 \mathrm{kcal} / \mathrm{mol}$ range to the barrier of reductive elimination of (POCOP) $\operatorname{Ir}(\mathrm{H})\left(\mathrm{Ar}^{\prime}\right)$ ( $\mathrm{Ar}^{\prime}-=$ $3,5-\mathrm{Me}_{2} \mathrm{C}_{6} \mathrm{H}_{3^{-}}$) of $14.1 \mathrm{kcal} / \mathrm{mol}$. ${ }^{39}$ This likely reflects a stronger Ir-N bond relative to the IrC bond. ${ }^{36}$ 
d) Reaction of (POCOP)Ir(H)(NHAr) Complexes $(14 e, f)$ with carbon monoxideGeneration of the tolyl hydrides 17 at $-78^{\circ} \mathrm{C}$ as described above followed by treatment with $\mathrm{C}_{6} \mathrm{~F}_{5} \mathrm{NH}_{2}$ (ca. 1.1 equiv.) and $\mathrm{CO}$ resulted in formation of (POCOP) $\operatorname{Ir}(\mathrm{CO})(\mathrm{H})\left(\mathrm{NHC}_{6} \mathrm{~F}_{5}\right)$, 20f, as the major product via CO trapping of $\mathbf{1 4 f}$. (Minor amounts of (POCOP)IrCO, 15, are formed presumably by $\mathrm{CO}$ displacement of aniline from (POCOP) $\mathrm{Ir}\left(\mathrm{NH}_{2} \mathrm{C}_{6} \mathrm{~F}_{5}\right)$ since reductive elimination of aniline from either $\mathbf{1 4 f}$ or $20 \mathrm{f}$ is very slow at $-78^{\circ} \mathrm{C}$.) Removal of toluene and addition of a minimal amount of pentane at $78^{\circ} \mathrm{C}$ resulted in the precipitation of $20 \mathrm{f}$ in low yield. Key NMR parameters of $20 f$ include a ${ }^{31} \mathrm{P}$ signal at $157 \mathrm{ppm}$ and a ${ }^{1} \mathrm{H}$ resonance for the iridium hydride at $-8.6 \mathrm{ppm}$. The downfield hydride shift is indicative of ligand coordination trans to the apical hydride. A solution of $20 \mathrm{f}$ in toluene at $25^{\circ} \mathrm{C}$ undergoes slow reductive elimination; (POCOP) $\operatorname{Ir}(\mathrm{CO})$ and free pentafluoroaniline are visible by ${ }^{1} \mathrm{H}$ NMR spectroscopy after 18 hours.

$\mathrm{X}$-ray quality crystals of $\mathbf{2 0 f}$ were obtained through slow crystallization from pentane at $-35^{\circ}$ C. The ORTEP diagram of $\mathbf{2 0 f}$ (Figure 4) indicates an Ir(III) octahedral complex with the CO bound in an apical site trans to the hydride and the aniline ligand trans to $\mathrm{C}_{\mathrm{ipso}}$. Since the crystal structure of $\mathbf{1 4 f}$ showed an empty coordination site in the position trans to the hydride, $\mathrm{CO}$ coordination to this site is consistent with rapid addition of $\mathrm{CO}$ to generate $\mathbf{2 0 f}$ as the kinetic product. Interestingly, there is a change in the orientation of the aniline ligand upon binding of CO. As mentioned earlier, in $\mathbf{1 4 f}$ the dihedral angle $\mathrm{H}-\operatorname{Ir}(1)-\mathrm{N}(1)-\mathrm{H}$ was $177^{\circ}$ with the hydride and $N$-H trans to each other. The dihedral angle $\mathrm{H}(1)-\operatorname{Ir}(1)-\mathrm{N}(11)-\mathrm{H}(11)$ in 20 after $\mathrm{CO}$ coordination is now $42^{\circ}$, indicating that the aniline ligand has rotated ca. $125^{\circ}$ and the hydride and $\mathrm{N}-\mathrm{H}$ are now nearly cis to each other.

Reaction of (POCOP)Ir(H)(NHAr- $\left.p \mathrm{CF}_{3}\right)(\mathbf{1 4 e})$ with $\mathrm{CO}$ was also investigated. Complex 14e was generated in situ at $25^{\circ} \mathrm{C}$ by treatment of tolyl hydrides 17 with $\mathrm{CF}_{3} \mathrm{C}_{6} \mathrm{H}_{4} \mathrm{NH}_{2}$ (ca. 1.5 equiv) at $25^{\circ} \mathrm{C}$. Cooling the toluene solution to $-78^{\circ} \mathrm{C}$ and purging with $\mathrm{CO}$ resulted in formation of four complexes. The major product was the expected $\mathrm{CO}$ addition product, (POCOP) $\operatorname{Ir}(\mathrm{H})(\mathrm{CO})\left(\mathrm{NHC}_{6} \mathrm{H}_{5}-p \mathrm{CF}_{3}\right)$, 20e. The ${ }^{1} \mathrm{H}$ and ${ }^{31} \mathrm{P}$ NMR data support a structure analogous to 20f. Two minor complexes corresponded to para and meta tolyl hydride carbonyl complexes (POCOP) $\operatorname{Ir}($ tolyl $)(\mathrm{H})(\mathrm{CO})$. These structures were fully characterized by $2 \mathrm{D}^{1} \mathrm{H}$ NMR spectroscopy and independently generated by treatment of 17 with CO. Distinct ${ }^{1} \mathrm{H}$ NMR signals for these complexes are the downfield shifts (8.05-8.16ppm) of the aryl protons ortho to Ir, and the two Ir hydride triplets at -8.69 and $-8.70 \mathrm{ppm}$. The fourth complex, also verified by independent synthesis, is $(\mathrm{POCOP}) \operatorname{Ir}(\mathrm{H})(\mathrm{Cl})(\mathrm{CO})$ from $\mathrm{CO}$ trapping of unreacted starting material. By increasing the concentration of aniline used, formation of the tolyl complexes was inhibited. We were unable to crystallize 20e and column chromatography resulted in its decomposition.

Complex 20e undergoes reductive elimination at a much slower rate than the five-coordinate analogue 14e. Heating an in situ generated toluene- $d_{8}$ solution of $(\mathrm{POCOP}) \operatorname{Ir}(\mathrm{H})(\mathrm{CO})(\mathrm{NHAr}-$ $\left.p \mathrm{CF}_{3}\right), 20 \mathrm{e}$, at $63^{\circ} \mathrm{C}$ results in the formation of (POCOP) $\operatorname{Ir}(\mathrm{CO})$ and free 4-

trifluoromethylaniline. In contrast, reductive elimination of five-coordinate $14 \mathrm{e}$ occurs at $9^{\circ} \mathrm{C}$. A detailed kinetic analysis of the reductive elimination was not carried out due to the difficulties in preparing 20e cleanly and complications due to the presence of excess product aniline.

However, qualitatively the rate of reductive elimination is retarded when carried out under 13 atmospheres of carbon monoxide. This is consistent with loss of $\mathrm{CO}$ to form five-coordinate 14e prior to reductive elimination as might be expected based on previous work concerning reductive elimination of six-coordinate $\mathrm{Pt}(\mathrm{IV})$ complexes. ${ }^{40}$ 


\section{II) Reaction of the (POCOP)Ir pincer complex with benzamides $\mathrm{C}_{6} \mathrm{H}_{5}(\mathrm{CO}) \mathrm{NH}_{2}(21 \mathrm{a})$ and $\mathrm{C}_{6} \mathrm{~F}_{5}(\mathrm{CO}) \mathrm{NH}_{2}(21 \mathrm{~b})$}

Reaction of (POCOP)Ir, 10, (generated by reaction of (POCOP) $\operatorname{Ir}(\mathrm{H})(\mathrm{Cl})$, 9, with $\mathrm{NaO} t \mathrm{Bu}$ ) with $\mathrm{NH}_{2}(\mathrm{CO}) \mathrm{C}_{6} \mathrm{H}_{5}, \mathbf{2 1 a}$, and $\mathrm{NH}_{2}(\mathrm{CO}) \mathrm{C}_{6} \mathrm{~F}_{5}, \mathbf{2 1}$, yields $\mathrm{Ir}(\mathrm{III})$ oxidative addition adducts 22a,b (Eq. 12). These adducts are substantially more stable than the anilino hydrides and can be readily isolated as stable solids at room temperature.

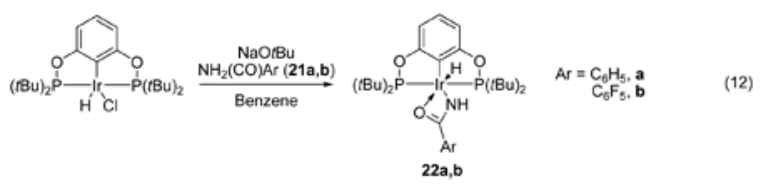

An X-Ray diffraction study was carried out on a crystal of $\mathbf{2 2} \mathbf{b}$ obtained from pentane at $-35^{\circ}$ C. The ORTEP diagram is shown in Figure 6 along with key bond distances and angles. Like the anilino complexes, the amide nitrogen lies in the square plane trans to Cipso of the aryl ring of the POCOP ligand. The N-C-O amide plane is perpendicular to the iridium square plane with the carbonyl oxygen anti to the axial Ir-H. The Ir-O bond distance of $2.55 \AA$ suggests weak coordination of the amide oxygen to the open axial site trans to hydride. It is of interest to compare the iridium-oxygen bond distance in $\mathbf{2 2} \mathbf{b}$ with Ir-O distances in other iridium amide complexes $\mathbf{2 3}^{41}, \mathbf{2 4}^{42}, \mathbf{2 5}^{43}$ shown in Figure 5 In the eighteen-electron Ir(III) complexes 23 and 24 the Ir-O distances of 3.401A and 3.412A clearly show no Ir-O interaction. The $\operatorname{Ir}(\mathrm{III})$ complex 25 is formally a sixteen-electron complex in the absence of a Ir-O interaction. The IrO distance of $2.290 \AA$ is considerably shorter than the Ir-O distances in $\mathbf{2 3}$ and $\mathbf{2 4}$ and clearly suggests a significant bonding interaction. The fact that the amide in $\mathbf{2 5}$ is an alkyl amide with a much more basic oxygen then that in the benzamide of $\mathbf{2 2} \mathbf{b}$ with a strongly electronwithdrawing $\mathrm{C}_{6} \mathrm{~F}_{5}$ group may in part account for the shorter Ir-O distance in $\mathbf{2 5}$.

The ${ }^{1} \mathrm{H}$ chemical shifts of the hydride ligands in 22a and $\mathbf{2 2} \mathbf{b}$ also support an axial Ir-O interaction. (POCOP)Ir hydride complexes with an empty coordination site trans to hydride exhibit hydride shifts in the $-41 \mathrm{ppm}$ range. In six-coordinate complexes the hydride shifts to much lower values. For example, in carbonyl adduct 20f, the ${ }^{1} \mathrm{H}$ shift is -8.56 . The intermediate shifts of the hydrides in 22a and 22b of -30.25 and -35.72 support a significant Ir-O interaction. The higher field shift of $-35.7 \mathrm{ppm}$ in $\mathbf{2 2 \mathbf { b }}$ suggests a decreased Ir-O interaction compared to 22a, consistent with a decreased oxygen basicity due to the strongly electron-withdrawing $\mathrm{C}_{6} \mathrm{~F}_{5}$ group.

\section{a) Rates of reductive elimination of $\mathrm{H}_{2} \mathrm{~N}(\mathrm{CO}) \mathrm{C}_{6} \mathrm{H}_{5}$ from (POCOP) $\operatorname{lr}(\mathrm{H})(\mathrm{NH}(\mathrm{CO})$} $\mathrm{C}_{6} \mathrm{H}_{5}$ ) Complexes-Since benzamides form significantly more stable $\operatorname{Ir}(\mathrm{III})$ species than their analogous aniline complexes, the rates of reductive elimination were measured at $100^{\circ}$ C. Ethylene proved to be a poor choice for a trapping ligand since ethylene concentrations were difficult to control at elevated temperatures. Therefore, triphenyl phosphine which competes reversibly with benzamide for coordination to irdium was used. The equilibrium between (POCOP) $\operatorname{Ir}(\mathrm{H})(\mathrm{NH}(\mathrm{CO}) \mathrm{Ph}), \mathbf{2 2 a},+\mathrm{PPh}_{3}$ and $(\mathrm{POCOP}) \operatorname{Ir}\left(\mathrm{PPh}_{3}\right)+\mathrm{H}_{2} \mathrm{~N}(\mathrm{CO}) \mathrm{C}_{6} \mathrm{H}_{5}$ as shown in Eq. 13 was measured at three different concentrations of $\mathrm{PPh}_{3}(0.29,0.59$, and $1.18 \mathrm{M})$ at $100^{\circ} \mathrm{C}$. From these data a $\mathrm{K}_{\mathrm{eq}}$ of 0.18 favoring $22 \mathrm{a}$ was calculated. For the more electronwithdrawing pentafluorbenzamide complex $\mathbf{2 2 b}$, the equilibrium constant decreases to 0.07 consistent with the substituent effects observed in the aniline equilibrium studies. At room temperature a one to one ratio of benzamide $21 \mathrm{a}(0.0094 \mathrm{M})$ and triphenylphoshine $(0.0094 \mathrm{M})$ was added to $10(0.0046 \mathrm{M})$, generated in the usual manner. ${ }^{31} \mathrm{P}$ NMR analysis showed the formation of 22a and 26 in a ratio of 2:1. Since interconversion of these species is slow at $25^{\circ}$ $\mathrm{C}$, this ratio represents kinetic trapping and differs from the thermodynamic ratio of ca. 6:1. 


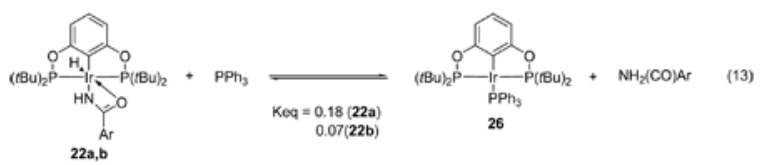

Generating 22a and analyzing the reversible reaction (Eq. 13) in the presence of 10 equiv. of 21a and 10 equiv. of $\mathrm{PPh}_{3}$, the half-life for reductive elimination of benzamide was found to be ca. 1.7 hours, corresponding to a $\Delta \mathrm{G}^{\ddagger}$ of ca. $29 \mathrm{kcal} / \mathrm{mol}$. This increased barrier to reductive elimination of benzamide relative to that for anilines is due to stronger binding of the benzamido fragment to (POCOP)Ir. The Ir-O interaction as well as a decrease in the repulsive $d \pi-p$ interaction as a result of the electron-withdrawing ability of the acyl moiety can account for the increased binding energy.

\section{Summary}

Reaction of a series of anilines 11a-g with (POCOP) $\operatorname{Ir}\left(\mathrm{C}_{6} \mathrm{H}_{5}\right)(\mathrm{H}), \mathbf{1 2}$, leads to equilibrium mixtures of 12, the $\operatorname{Ir}(\mathrm{I}) \sigma$-complexes (POCOP) $\operatorname{Ir}\left(\mathrm{NH}_{2} \mathrm{Ar}\right), \mathbf{1 3}$, and the $\operatorname{Ir}(\mathrm{III})$ oxidative addition adducts (POCOP) $\operatorname{Ir}(\mathrm{H})(\mathrm{NHAr}), \mathbf{1 4}$. Previous studies have shown that 12 undergoes rapid reductive elimination of benzene to form the 14-electron species (POCOP)Ir, 10, so complexes $\mathbf{1 3}$ and $\mathbf{1 4}$ arise from reaction of anilines with $\mathbf{1 0}$. Equilibrium constants connecting these three species have been measured and several features are apparent. As expected, as the basicity of the aniline increases, the equilibrium ratio of $\mathbf{1 3}$ + benzene: $\mathbf{1 2}$ + aniline increases. Surprisingly, however, as the basicity of the aniline decreases, the ratio of the $\operatorname{Ir}(\mathrm{III})$ species 14, to $\operatorname{Ir}(\mathrm{I})$ species 13 increases, as does the ratio of $\mathbf{1 4}+$ benzene: $\mathbf{1 2}+$ aniline. The increased stability of the oxidative addition adducts bearing electron-withdrawing aryl groups $\left(-p \mathrm{CF}_{3} \mathrm{C}_{6} \mathrm{H}_{4} \mathbf{1 4 e}\right.$, $\left.\mathrm{C}_{6} \mathrm{~F}_{5} \mathbf{1 4 f}, 3,5-\left(\mathrm{CF}_{3}\right)_{2} \mathrm{C}_{6} \mathrm{~F}_{3}-\mathbf{1 4 g}\right)$ was attributed to decreased repulsion between the filled $d \pi$ and $N$-p orbitals.

Low temperature NMR experiments employing $p$-chloroaniline show that reaction with $\mathbf{1 2}$ forms the $\operatorname{Ir}(\mathrm{I}) \sigma$-complex (POCOP) $\operatorname{Ir}\left(\mathrm{NH}_{2} \mathrm{C}_{6} \mathrm{H}_{4} \mathrm{Cl}\right), \mathbf{1 3 d}$, as the kinetic product which equilibrates with the oxidative addition adduct $14 \mathrm{~d}$ at temperatures above $-50^{\circ} \mathrm{C}$. Complexes 14e-g undergo reductive elimination at $9^{\circ} \mathrm{C}$ in the presence of ethylene to yield quantitatively (POCOP) $\operatorname{Ir}\left(\mathrm{C}_{2} \mathrm{H}_{4}\right), 18$, and the respective aniline. Rate measurements demonstrate that these reactions are cleanly first-order and independent of ethylene concentration. Mechanistic analysis suggests that the rate-determining step is formation of the $\sigma$-complex followed by loss of the aniline to form $\mathbf{1 0}$ which is rapidly trapped by ethylene. The reductive elimination barriers of 14e-g fall in the range of $21-22 \mathrm{kcal} / \mathrm{mol}$ and increase with electron-withdrawing ability of the aryl groups.

Complex $14 \mathrm{f}$ is square pyramidal with the hydride occupying the apical site. Trapping $14 \mathrm{f}$ with $\mathrm{CO}$ forms the 18-electron complex (POCOP) $\operatorname{Ir}(\mathrm{H})(\mathrm{CO})\left(\mathrm{NHC}_{6} \mathrm{~F}_{5}\right)$, 20f. X-Ray analysis of a single crystal of $20 \mathrm{f}$ indicates $\mathrm{CO}$ has added at the vacant site trans to hydride. The sixcoordinate $\mathrm{CO}$ adducts are much more stable with respect to reductive elimination. Complex 20e undergoes reductive elimination at $72^{\circ} \mathrm{C}$ at rates similar to $14 \mathrm{e}$ reductive elimination at $9^{\circ}$ C. Qualitative rate measurements suggest $\mathrm{CO}$ must dissociate prior to reductive elimination.

Reaction of 12 with benzamides yields quantatively the $\operatorname{Ir}(\mathrm{III})$ oxidative addition adducts, $(\mathrm{POCOP}) \operatorname{Ir}(\mathrm{H})(\mathrm{NHC}(\mathrm{O}) \mathrm{Ar}), 22$. X-Ray analysis of $\mathbf{2 2} \mathbf{b}\left(\mathrm{Ar}=\mathrm{C}_{6} \mathrm{~F}_{5}\right)$ shows significant interaction of the carbonyl oxygen with Ir in the site trans to hydride. The barrier to reductive elimination of 22a, $29 \mathrm{kcal} / \mathrm{mol}$, is substantially higher than for complexes $\mathbf{1 4 e , f , g . ~ T h e ~}$ increased binding energy of the $-\mathrm{NH}(\mathrm{CO})$ Ar group to Ir is ascribed to Ir-O interaction as well as a decrease in the repulsive $d \pi-p$ interaction as a result of the strong electron-withdrawing ability of the acyl moiety. 


\section{Experimental Section}

\section{General Considerations}

All manipulations were carried out using standard Schlenk, high-vacuum, and glove box techniques. Argon and nitrogen were purified by passage through columns of BASF R3-11 (chemalog) and $4 \AA$ molecular sieves. THF was distilled from sodium benzophenone ketyl under nitrogen. Pentane and toluene were passed through columns of activated alumina and deoxygenated by purging with $\mathrm{N}_{2}$. Benzene was dried with $4 \AA$ molecular sieves and degassed by either freeze-pump-thaw methods or by purging with argon. Toluene was further treated by purging with argon to remove nitrogen. Toluene- $d_{8}$ and benzene- $d_{6}$ were dried over $4 \AA$ molecular sieves and stored under argon in the glove box. Hydrogen and carbon monoxide were used as received from National Specialty Gases of Durham, NC. NMR spectra were recorded on Bruker DRX 400, AMX 300 and $500 \mathrm{MHz}$ instruments and are referenced to residual protio solvent peaks. ${ }^{31} \mathrm{P}$ chemical shifts are referenced to an external $\mathrm{H}_{3} \mathrm{PO}_{4}$ standard. Since there is a strong ${ }^{31} \mathrm{P}_{-}{ }^{31} \mathrm{P}$ coupling in the pincer complexes, many of the ${ }^{1} \mathrm{H}$ and ${ }^{13} \mathrm{C}$ signals exhibit virtual coupling and appear as triplets. These are specified as vt with the apparent coupling simply noted as $J$. IR spectra were recorded on an ASI ReactIR 1000 spectrometer. Elemental analyses were carried out by Atlantic Microlab, Inc. of Norcross, GA. All reagents were purchased from Sigma-Aldrich and used without further purification. The POCOP bis(phosphinite) ligand and (POCOP) $\operatorname{Ir}(\mathrm{H})(\mathrm{Cl}), \mathbf{9}$, were prepared by literature procedures ${ }^{30}$. The $[\mathrm{IrCODCl}]_{2}$ can be purchased from Strem or synthesized using literature procedures. ${ }^{44}$

\section{(POCOP)Ir(H)(Ph) (12)}

Complex 12 was generated in situ by treatment of $(\mathrm{POCOP}) \operatorname{Ir}(\mathrm{H})(\mathrm{Cl}), \mathbf{9}$, with 1.1 equiv. of $\mathrm{NaOtBu}$ in benzene at $75^{\circ} \mathrm{C}$ for 30 minutes. 29

\section{General Procedure for the in situ generation of complexes 13 and 14}

$(\mathrm{POCOP}) \operatorname{Ir}(\mathrm{H})(\mathrm{Cl}) 2$ was placed in a medium-walled screw-cap NMR tube with 1.1 equiv. of $\mathrm{NaO} t \mathrm{Bu}$ in $0.5 \mathrm{~mL}$ of benzene or toluene and heated to $75^{\circ} \mathrm{C}$ for 45 minutes to generate the aryl hydride complex. The aniline was added to this mixture and allowed to react for 45 minutes at room temperature.

\section{(POCOP)Ir $\left(\mathrm{NH}_{2}\left(p-\mathrm{OCH}_{3} \mathrm{C}_{6} \mathrm{H}_{4}\right)\right)(13 \mathrm{a})$}

The general procedure was employed using $\mathbf{9}(0.033 \mathrm{mmol}, 21 \mathrm{mg}), \mathrm{NaO} t \mathrm{Bu}(0.037 \mathrm{mmol}, 3.5$ $\mathrm{mg})$ and 11a (0.099 mmol, $13.5 \mathrm{mg})$.

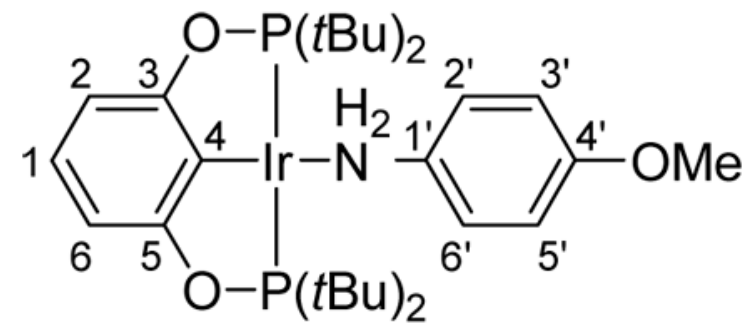

\section{$13 a$}

${ }^{1} \mathrm{H}$ NMR $\left(300 \mathrm{MHz}, \mathrm{C}_{6} \mathrm{D}_{6}\right): \delta 6.99\left(\mathrm{~d},{ }^{3} J_{\mathrm{H}-\mathrm{H}}=8.7 \mathrm{~Hz}, 2 \mathrm{H}, 2^{\prime}-\right.$ and $\left.66^{\prime}-\mathrm{H}\right), 6.95\left(\mathrm{t},{ }^{3 \mathrm{~J}} \mathrm{H}-\mathrm{H}=7.8\right.$ $\mathrm{Hz}, 1 \mathrm{H}, 1-\mathrm{H}), 6.83\left(\mathrm{~d},{ }^{3} J_{\mathrm{H}-\mathrm{H}}=7.8 \mathrm{~Hz}, 2 \mathrm{H}, 2-\right.$ and $\left.6-\mathrm{H}\right), 6.59\left(\mathrm{~d},{ }^{3} J_{\mathrm{H}-\mathrm{H}}=8.7 \mathrm{~Hz}, 2 \mathrm{H}, 3^{\prime}-\right.$ and $5 '-\mathrm{H}), 5.15\left(\mathrm{~s}, 2 \mathrm{H},-\mathrm{NH}_{2}\right), 3.29\left(\mathrm{~s}, 3 \mathrm{H}, \mathrm{OCH}_{3}\right), 1.28\left(\mathrm{vt}, J=6.5 \mathrm{~Hz}, 36 \mathrm{H}, 2 \times \mathrm{P}(t \mathrm{Bu})_{2}\right) .{ }^{31} \mathrm{P}$ 
$\left\{{ }^{1} \mathrm{H}\right\}$ NMR (121.5 MHz, $\left.\mathrm{C}_{6} \mathrm{D}_{6}\right): \delta 173.6 .{ }^{13} \mathrm{C}\left\{{ }^{1} \mathrm{H}\right\} \mathrm{NMR}\left(75.5 \mathrm{MHz}, \mathrm{C}_{6} \mathrm{D}_{6}\right): \delta 167.9\left(\mathrm{C}_{\mathrm{q}}, \mathrm{vt}\right.$, $J=8.6 \mathrm{~Hz}, \mathrm{C} 3$ and $\mathrm{C} 5), 158.2\left(\mathrm{C}_{\mathrm{q}}, \mathrm{s}, \mathrm{C}^{\prime}\right), 138.5\left(\mathrm{C}_{\mathrm{q}}, \mathrm{s}, \mathrm{C} 1^{\prime}\right), 124.6\left(\mathrm{CH}, \mathrm{s}, \mathrm{C} 3^{\prime}\right.$ and $\left.\mathrm{C}^{\prime}\right), 121.3$ $(\mathrm{CH}, \mathrm{s}, \mathrm{C} 1), 114.1\left(\mathrm{CH}, \mathrm{s}, \mathrm{C}^{\prime}\right.$ and $\left.\mathrm{C}^{\prime}\right), 103.3(\mathrm{CH}, \mathrm{vt}, J=5.7 \mathrm{~Hz}, \mathrm{C} 2$ and $\mathrm{C} 6), 55.2\left(\mathrm{CH}_{3}, \mathrm{~s}\right.$, $\left.\mathrm{OCH}_{3}\right), 41.1\left(\mathrm{C}_{\mathrm{q}}, \mathrm{vt}, J=11.0 \mathrm{~Hz}, \mathrm{C}\left(\mathrm{CH}_{3}\right)_{3}\right), 28.6\left(\mathrm{CH}_{3}, \mathrm{vt},{ }^{2} J_{\mathrm{P}-\mathrm{H}}=3.8 \mathrm{~Hz}, \mathrm{C}\left(\mathrm{CH}_{3}\right)_{3}\right)$. C4 not observed due to low intensity.

(POCOP)Ir( $\left.\mathrm{NH}_{2} \mathrm{Ar}-\mathrm{Me}\right)$ (13b)

The general procedure, $\mathbf{1 3 b}$ was employed using $\mathbf{9}(0.035 \mathrm{mmol}, 22 \mathrm{mg}), \mathrm{NaO} t \mathrm{Bu}(0.038 \mathrm{mmol}$, $3.9 \mathrm{mg})$ and $\mathbf{1 1 b}(0.1 \mathrm{mmol}, 11 \mathrm{mg})$.

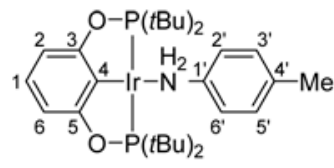

$13 b$

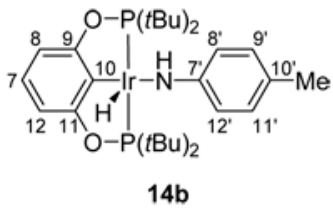

$14 b$

${ }^{1} \mathrm{H}$ NMR (400 MHz, $\left.\mathrm{C}^{6} \mathrm{D}^{6}\right)$ : 13b: $\delta 6.77-6.96\left(7 \mathrm{H}\right.$, aromatic protons), 5.17 (s, 2H, $-\mathrm{NH}_{2}$ ), $2.04\left(\mathrm{~s}, 3 \mathrm{H}, \mathrm{CH}_{3}\right), 1.27\left(\mathrm{vt}, J=6.4 \mathrm{~Hz}, 36 \mathrm{H}, 2 \times \mathrm{P}(t \mathrm{Bu})_{2}\right)$. 14b: Concentration of $\mathbf{1 4 b}$ is very low, resulting in the only distinguishing ${ }^{1} \mathrm{H}$ resonance as the hydride, $-33.25\left(\mathrm{t}, J_{\mathrm{P}-\mathrm{H}}=12.7\right.$ $\mathrm{Hz}, 1 \mathrm{H}, \mathrm{Ir}-H) .{ }^{31} \mathrm{P}\left\{{ }^{1} \mathrm{H}\right\}$ NMR $\left(121.5 \mathrm{MHz}, \mathrm{C}_{6} \mathrm{D}_{6}\right): \delta 173.6(\mathbf{1 3 b}), 171.3(\mathbf{1 4 b}) .{ }^{13} \mathrm{C}\left\{{ }^{1} \mathrm{H}\right\} \mathrm{NMR}$ $\left(100.6 \mathrm{MHz}, \mathrm{C}_{6} \mathrm{D}_{6}\right)$ : 13b: $\delta 167.8\left(\mathrm{C}_{\mathrm{q}}, \mathrm{vt}, J=8.7 \mathrm{~Hz}, \mathrm{C} 3\right.$ and $\left.\mathrm{C} 5\right), 144.7\left(\mathrm{C}_{\mathrm{q}}, \mathrm{s}, \mathrm{C} 11^{\prime}\right), 135.3$ $\left(\mathrm{C}_{\mathrm{q}}, \mathrm{s}, \mathrm{C} 4^{\prime}\right), 129.4\left(\mathrm{CH}, \mathrm{s}, \mathrm{C} 2^{\prime}\right.$ and $\left.\mathrm{C6}^{\prime}\right), 127\left(\mathrm{C}_{\mathrm{q}}, \mathrm{C} 4\right), 123.1\left(\mathrm{CH}, \mathrm{s}, \mathrm{C}^{\prime}\right.$ and $\left.\mathrm{C5}^{\prime}\right), 121.2(\mathrm{CH}$, s, C1), $103.2\left(\mathrm{CH}, \mathrm{vt}, J=5.9 \mathrm{~Hz}, \mathrm{C} 2\right.$ and C6), $41.1\left(\mathrm{C}_{\mathrm{q}}\right.$, vt, $\left.J=11.0 \mathrm{~Hz}, C\left(\mathrm{CH}_{3}\right)_{3}\right), 28.5$ $\left(\mathrm{CH}_{3}, \mathrm{vt}, J=3.4 \mathrm{~Hz}, \mathrm{C}\left(\mathrm{CH}_{3}\right)_{3}\right), 20.6\left(\mathrm{CH}_{3}, \mathrm{~s}, \mathrm{CH}_{3}\right)$.

\section{(POCOP) Ir( $\left.\mathrm{NH}_{2} \mathrm{C}_{6} \mathrm{H}_{5}\right)(13 \mathrm{c}) /(\mathrm{POCOP}) \operatorname{Ir}(\mathrm{H})\left(\mathrm{NHC}_{6} \mathrm{H}_{5}\right)(14 \mathrm{c})$}

The general procedure was employed using $9(0.024 \mathrm{mmol}, 15 \mathrm{mg}), \mathrm{NaO} t \mathrm{Bu}(0.026 \mathrm{mmol}, 2.5$ $\mathrm{mg})$ and $11 \mathrm{c}(0.048 \mathrm{mmol}, 4.4 \mu \mathrm{L})$. The equilibrating set of complexes 12, 13c and $14 \mathrm{c}$ as well as $10 \%$ unreacted 9 were all present in the sample thus the ${ }^{13} \mathrm{C}$ NMR spectrum was not useful for structural assignments.

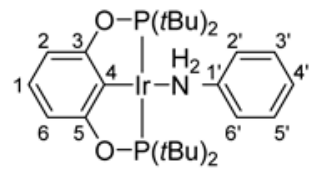

$13 c$

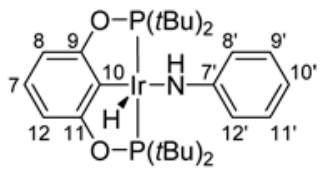

$14 \mathrm{c}$

${ }^{1} \mathrm{H}$ NMR (400 MHz, $\mathrm{C}_{6} \mathrm{D}_{6}$ ): 13c: $\delta 6.69-6.96$ (aromatic protons), 5.19 (s, $2 \mathrm{H}, \mathrm{NH}_{2}$ ), 1.26 (vt, $\left.J=6.4 \mathrm{~Hz}, 36 \mathrm{H}, \mathrm{P}(t \mathrm{Bu})_{2}\right), \mathbf{1 4 c}$ : The concentration of $\mathbf{1 4 c}$ is very low, resulting in the only distinguishing ${ }^{1} \mathrm{H}$ resonance as the hydride, $-34.05(\mathrm{t}, J=12.6 \mathrm{~Hz}) .{ }^{31} \mathrm{P}\left\{{ }^{1} \mathrm{H}\right\} \mathrm{NMR}(162 \mathrm{MHz}$, $\left.\mathrm{C}_{6} \mathrm{D}_{6}\right): \delta 173.8(\mathbf{1 3 c}), 172.0(\mathbf{1 4 c})$.

\section{(POCOP)Ir( $\left.\mathrm{NH}_{2}\left(p-\mathrm{CIC}_{6} \mathrm{H}_{4}\right)\right)(13 \mathrm{~d}) /(\mathrm{POCOP}) \operatorname{Ir}(\mathrm{H})\left(\mathrm{NH}\left(p-\mathrm{ClC}_{6} \mathrm{H}_{4}\right)\right)(\mathbf{1 4 d})$}

The general procedure was employed using $9(0.024 \mathrm{mmol}, 15 \mathrm{mg}), \mathrm{NaO} t \mathrm{Bu}(0.026 \mathrm{mmol}, 2.5$ $\mathrm{mg})$ and $11 \mathrm{~d}(0.048 \mathrm{mmol}, 6.1 \mu \mathrm{L})$. The equilibrating set 12, 13d and 14d, as well as $3 \%$ unreacted 9 were present in the NMR sample.

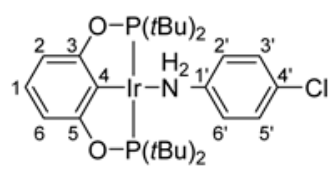

$13 d$

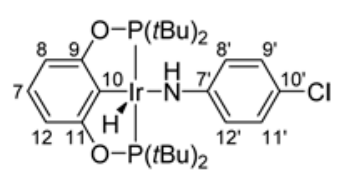

14d 
${ }^{1} \mathrm{H}$ NMR (400 MHz, $\left.\mathrm{C}_{6} \mathrm{D}_{6}\right): \delta 6.61-6.97(\mathrm{~m}, 14 \mathrm{H}$, aromatic protons for 13d and 14d), $5.60(\mathrm{~s}$, $1 \mathrm{H}, \mathrm{N} H), 5.06\left(\mathrm{~s}, 2 \mathrm{H}, \mathrm{NH}_{2}\right), 1.08,1.24\left(\mathrm{~m}, 72 \mathrm{H}, \mathrm{P}(t \mathrm{Bu})_{2}\right),-35.94\left(\mathrm{t}, J_{\mathrm{P}-\mathrm{H}}=13.2 \mathrm{~Hz}, 1 \mathrm{H}\right.$, Ir $H) .{ }^{31} \mathrm{P}\left\{{ }^{1} \mathrm{H}\right\}$ NMR $\left(162 \mathrm{MHz}, \mathrm{C}_{6} \mathrm{D}_{6}\right): \delta 173.9$ (13d), 172.6 (14d).

\section{(POCOP)Ir(H)(NH(p-CF $\left.\left.\mathrm{C}_{6} \mathrm{H}_{4}\right)\right)(14 \mathrm{e})$}

The general procedure was employed using $9(0.032 \mathrm{mmol}, 20 \mathrm{mg}), \mathrm{NaO} t \mathrm{Bu}(0.032 \mathrm{mmol}, 3.1$ $\mathrm{mg})$ and $11 \mathrm{e}(0.08 \mathrm{mmol}, 10 \mu \mathrm{L})$.

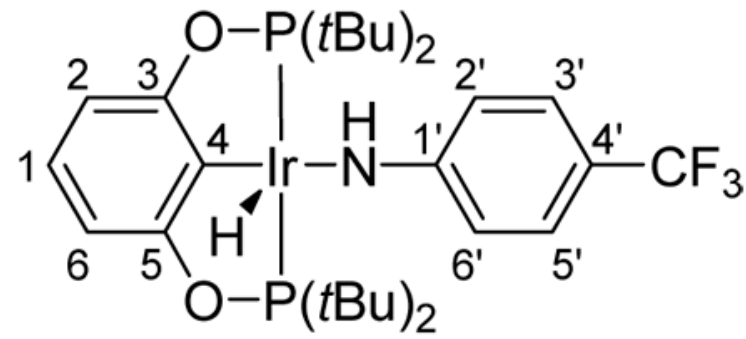

\section{$14 \mathrm{e}$}

${ }^{1} \mathrm{H}$ NMR $\left(500 \mathrm{MHz}, \mathrm{C}_{6} \mathrm{D}_{6}\right): \delta 7.43\left(\mathrm{~d},{ }^{3} J_{\mathrm{H}-\mathrm{H}}=8.5 \mathrm{~Hz}, 2 \mathrm{H}, 3^{\prime}-\right.$ and $\left.5^{\prime}-\mathrm{H}\right), 6.82\left(\mathrm{t},{ }^{3} J_{\mathrm{H}-\mathrm{H}}=7.8\right.$ $\mathrm{Hz}, 1 \mathrm{H}, 1-\mathrm{H}), 6.73\left(\mathrm{~d},{ }^{3} J_{\mathrm{H}-\mathrm{H}}=8.0 \mathrm{~Hz}, 2 \mathrm{H}, 2-\right.$ and $\left.6-\mathrm{H}\right), 6.46\left(\mathrm{~d},{ }^{3} J_{\mathrm{H}-\mathrm{H}}=8.5 \mathrm{~Hz}, 2 \mathrm{H}, 2^{\prime}-\right.$ and 6'-H), 4.37 (s, 1H, NH), 1.108 (vt, $\left.J=7.5 \mathrm{~Hz}, 18 \mathrm{H}, \mathrm{P}(t \mathrm{Bu})_{2}\right), 1.046(\mathrm{vt}, J=7.0 \mathrm{~Hz}, 18 \mathrm{H}, \mathrm{P}$ $\left.(t \mathrm{Bu})_{2}\right),-40.265\left(\mathrm{t}, J_{\mathrm{P}-\mathrm{H}}=13.3 \mathrm{~Hz}, 1 \mathrm{H}, \mathrm{Ir} H\right) .{ }^{31} \mathrm{P}\left\{{ }^{1} \mathrm{H}\right\} \mathrm{NMR}\left(162 \mathrm{MHz}, \mathrm{C}_{6} \mathrm{D}_{6}\right): \delta 173.3 .{ }^{19} \mathrm{~F}$ $\operatorname{NMR}\left(376.5 \mathrm{MHz}, \mathrm{C}_{6} \mathrm{D}_{6}\right): \delta-59.1 .{ }^{13} \mathrm{C}\left\{{ }^{1} \mathrm{H}\right\} \operatorname{NMR}\left(125.8 \mathrm{MHz}, \mathrm{C}_{6} \mathrm{D}_{6}\right): \delta 168.0\left(\mathrm{C}_{\mathrm{q}}, \mathrm{vt}, J_{\mathrm{C}}=\right.$ $5.5 \mathrm{~Hz}, \mathrm{C} 3$ and C5), $164.0\left(\mathrm{C}_{\mathrm{q}}, \mathrm{s}, \mathrm{C} 1^{\prime}\right), 127.0\left(\mathrm{C}_{\mathrm{q}}, \mathrm{q},{ }^{1} J_{\mathrm{F}-\mathrm{C}}=238.9 \mathrm{~Hz}, \mathrm{CF}_{3}\right), 126.4(\mathrm{CH}$, $\mathrm{q},{ }^{3} J_{\mathrm{F}-\mathrm{C}}=3.6 \mathrm{~Hz}, \mathrm{C} 3{ }^{\prime}$ and $\left.\mathrm{C}^{\prime}\right), 126.3(\mathrm{CH}, \mathrm{s}, \mathrm{C} 1), 123.7\left(\mathrm{C}_{\mathrm{q}}, \mathrm{br}, \mathrm{C} 4\right), 117.1\left(\mathrm{CH}, \mathrm{s}, \mathrm{C} 2{ }^{\prime}\right.$ and $\left.\mathrm{C}^{\prime}\right), 112.7\left(\mathrm{C}_{\mathrm{q}}, \mathrm{q},{ }^{2} J_{\mathrm{F}-\mathrm{C}}=32.2 \mathrm{~Hz}, \mathrm{C} 4 '\right), 104.8\left(\mathrm{CH}, \mathrm{t}, J_{\mathrm{P}-\mathrm{H}}=5.2, \mathrm{C} 2\right.$ and $\left.\mathrm{C} 6\right), 42.7(\mathrm{Cq}, \mathrm{vt}$, $\left.J=10.8 \mathrm{~Hz}, C\left(\mathrm{CH}_{3}\right)_{3}\right), 38.9\left(\mathrm{Cq}, \mathrm{vt}, J=12.8 \mathrm{~Hz}, C\left(\mathrm{CH}_{3}\right)_{3}\right), 28.0\left(\mathrm{CH}_{3}, \mathrm{vt}, J=3.2 \mathrm{~Hz}, \mathrm{C}\right.$ $\left.\left(\mathrm{CH}_{3}\right)_{3}\right), 27.6\left(\mathrm{CH}_{3}\right.$, vt, $\left.J_{\mathrm{P}-\mathrm{H}}=3.2 \mathrm{~Hz}, \mathrm{C}\left(\mathrm{CH}_{3}\right)_{3}\right)$.

\section{$(\mathrm{POCOP}) \operatorname{Ir}(\mathrm{H})\left(\mathrm{NHC}_{6} \mathrm{~F}_{5}\right)(\mathbf{1 4 f})$}

Simultaneously, 9 (0.034 mmol, $21 \mathrm{mg}), \mathrm{NaO} t \mathrm{Bu}(0.037 \mathrm{mmol}, 3.6 \mathrm{mg}), 11 \mathrm{f}(0.068 \mathrm{mmol}$, $12.4 \mathrm{mg})$, and benzene- $\mathrm{d}_{6}(0.5 \mathrm{~mL})$ were added to a medium-walled screw-cap NMR tube and heated to $75^{\circ} \mathrm{C}$ for 1 hour.

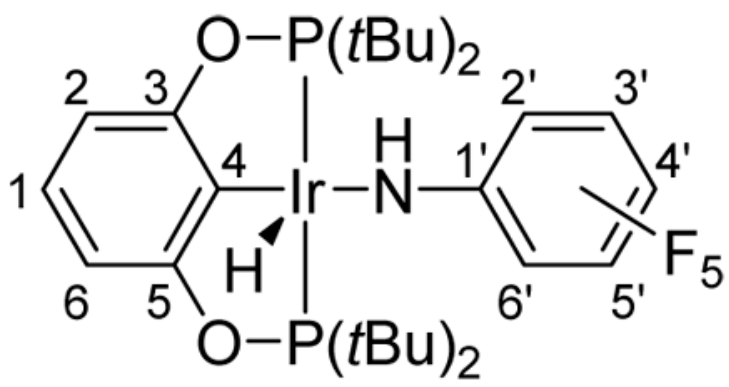

\section{$14 f$}

${ }^{1} \mathrm{H}$ NMR $\left(500 \mathrm{MHz}, \mathrm{C}_{6} \mathrm{D}_{6}\right): \delta 6.82-6.72(\mathrm{~m}, 3 \mathrm{H}, 1-, 2-, 6-\mathrm{H}), 3.01(\mathrm{~s}, 1 \mathrm{H}, \mathrm{NH}), 1.09-1.03(\mathrm{~m}$, $\left.36 \mathrm{H}, \mathrm{P}(t \mathrm{Bu})_{2}\right)-42.15\left(\mathrm{t}, J_{\mathrm{P}-\mathrm{H}}=13.5 \mathrm{~Hz}, 1 \mathrm{H}, \mathrm{Ir} H\right) .{ }^{31} \mathrm{P}\left\{{ }^{1} \mathrm{H}\right\} \mathrm{NMR}\left(162 \mathrm{MHz}, \mathrm{C}_{6} \mathrm{D}_{6}\right): \delta$ 172.8. ${ }^{19} \mathrm{~F}$ NMR (376.5 MHz, $\left.\mathrm{C}_{6} \mathrm{D}_{6}\right): \delta-167.3(\mathrm{~m}),-168.9(\mathrm{~m}),-187.3(\mathrm{~m}) .{ }^{13} \mathrm{C}\left\{{ }^{1} \mathrm{H}\right\}$ NMR $\left(125.8 \mathrm{MHz}, \mathrm{C}_{6} \mathrm{D}_{6}\right): \delta 168.5\left(\mathrm{C}_{\mathrm{q}}\right.$, vt, $J=5.5 \mathrm{~Hz}, \mathrm{C} 3$ and $\left.\mathrm{C} 5\right), 140.4-135.8\left(\mathrm{~m}, \mathrm{C}_{\mathrm{q}}, \mathrm{Ar}-\mathrm{F}_{5}: \mathrm{C}^{2}\right.$, 
C6', C3', C5', and C4'), $126.7(\mathrm{CH}, \mathrm{s}, \mathrm{C} 1), 122.6\left(\mathrm{C}_{\mathrm{q}}, \mathrm{t}, \mathrm{C} 4\right), 104.9\left(\mathrm{CH}, \mathrm{t}, \mathrm{J}_{\mathrm{P}-\mathrm{H}}=5.3 \mathrm{~Hz}, \mathrm{C} 2\right.$ and C6), $42.6\left(\mathrm{Cq}, \mathrm{vt}, J=11.1 \mathrm{~Hz}, C\left(\mathrm{CH}_{3}\right)_{3}\right), 39.1\left(\mathrm{Cq}, \mathrm{vt}, J=12.6 \mathrm{~Hz}, C\left(\mathrm{CH}_{3}\right)_{3}\right), 27.7$

$\left(\mathrm{CH}_{3}, \mathrm{vt}, J=3.2 \mathrm{~Hz}, \mathrm{C}\left(\mathrm{CH}_{3}\right)_{3}\right), 27.2\left(\mathrm{CH}_{3}, \mathrm{vt}, J=3.0 \mathrm{~Hz}, \mathrm{C}\left(\mathrm{CH}_{3}\right)_{3}\right)$. Cl' not observed due to low intensity.

\section{(POCOP) $\operatorname{Ir}(\mathrm{H})\left(\mathrm{NH}\left(\mathbf{3}, \mathbf{5 -}\left(\mathrm{CF}_{3}\right)_{2} \mathrm{C}_{6} \mathrm{H}_{3}\right)\right)(\mathbf{1 4 g})$}

The general procedure was employed using $9(0.035 \mathrm{mmol}, 22 \mathrm{mg}), \mathrm{NaO} t \mathrm{Bu}(0.039 \mathrm{mmol}, 3.7$ $\mathrm{mg})$ and $\mathbf{1 1 g}(0.07 \mathrm{mmol}, 10.9 \mu \mathrm{L})$.

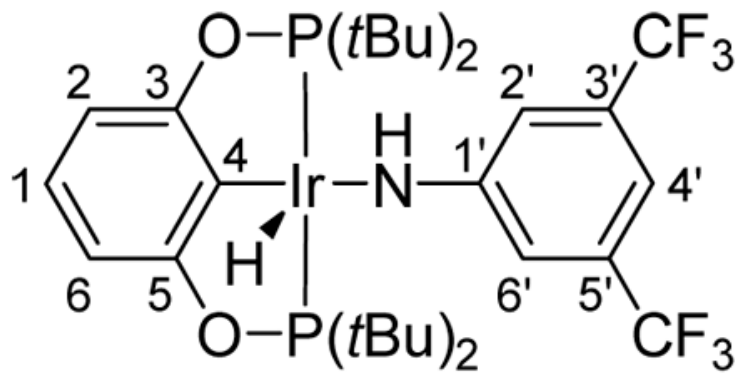

\section{$14 \mathrm{~g}$}

${ }^{1} \mathrm{H}$ NMR $\left(500 \mathrm{MHz}, \mathrm{C}_{6} \mathrm{D}_{6}\right): \delta 6.98\left(\mathrm{~s}, 1 \mathrm{H}, 4^{\prime}-\mathrm{H}\right), 6.87\left(\mathrm{~s}, 2 \mathrm{H}, 2^{\prime}-\right.$ and $\left.6 '-\mathrm{H}\right), 6.81\left(\mathrm{t},{ }^{3} J_{\mathrm{H}-\mathrm{H}}=\right.$ $7.9 \mathrm{~Hz}, 1 \mathrm{H}, 1-\mathrm{H}), 6.73\left(\mathrm{~d},{ }^{3} J_{\mathrm{H}-\mathrm{H}}=7.9 \mathrm{~Hz}, 2 \mathrm{H}, 2-\right.$ and 6-H), $3.74(\mathrm{~s}, 1 \mathrm{H}, \mathrm{NH}), 1.06$ (vt, $J=7.4$ $\left.\mathrm{Hz}, 18 \mathrm{H}, \mathrm{P}(t \mathrm{Bu})_{2}\right), 0.99\left(\mathrm{vt}, J=6.8 \mathrm{~Hz}, 18 \mathrm{H}, \mathrm{P}(t \mathrm{Bu})_{2}\right),-41.77\left(\mathrm{t}, J_{\mathrm{P}-\mathrm{H}}=13.5 \mathrm{~Hz}, 1 \mathrm{H}\right.$, $\mathrm{Ir} H) .{ }^{31} \mathrm{P}\left\{{ }^{1} \mathrm{H}\right\}$ NMR $\left(162 \mathrm{MHz}, \mathrm{C}_{6} \mathrm{D}_{6}\right): \delta 174.0$ (d). ${ }^{19} \mathrm{~F}$ NMR $\left(376.5 \mathrm{MHz}, \mathrm{C}_{6} \mathrm{D}_{6}\right): \delta$ $-63.2{ }^{13} \mathrm{C}\left\{{ }^{1} \mathrm{H}\right\} \operatorname{NMR}\left(125.8 \mathrm{MHz}, \mathrm{C}_{6} \mathrm{D}_{6}\right): \delta 168.5\left(\mathrm{C}_{\mathrm{q}}\right.$, vt, $J=5.6 \mathrm{~Hz}, \mathrm{C} 3$ and $\left.\mathrm{C} 5\right), 161.4$ $\left(\mathrm{C}_{\mathrm{q}}, \mathrm{s}, \mathrm{C} 1^{\prime}\right), 132.0\left(\mathrm{C}_{\mathrm{q}}, \mathrm{q},{ }^{2} J_{\mathrm{F}-\mathrm{C}}=31.4 \mathrm{~Hz}, \mathrm{C} 3{ }^{\prime}\right.$ and $\left.\mathrm{C}^{\prime}\right), 127.0(\mathrm{CH}, \mathrm{s}, \mathrm{C} 1), 125.5\left(\mathrm{C}_{\mathrm{q}}\right.$, q, $\left.{ }^{1} J_{\mathrm{F}-\mathrm{C}}=273.3 \mathrm{~Hz}, C \mathrm{~F} 3\right), 124.5\left(\mathrm{C}_{\mathrm{q}}, \mathrm{m}, \mathrm{C} 4\right), 115.7(\mathrm{CH}, \mathrm{m}, \mathrm{C} 2$ ' and $\mathrm{C} 6), 105.0(\mathrm{CH}, \mathrm{t}$, vt, $J=5.2 \mathrm{~Hz}, \mathrm{C} 2$ and C6), $102.4\left(\mathrm{CH}\right.$, septet, $\left.{ }^{3} J_{\mathrm{F}-\mathrm{C}}=4.0 \mathrm{~Hz}\right), 42.8(\mathrm{Cq}, \mathrm{vt}, J=10.9 \mathrm{~Hz}, C$ $\left.\left(\mathrm{CH}_{3}\right)_{3}\right), 38.7\left(\mathrm{Cq}, \mathrm{vt}, J=12.8 \mathrm{~Hz}, \mathrm{C}\left(\mathrm{CH}_{3}\right)_{3}\right), 28.0\left(\mathrm{CH}_{3}, \mathrm{vt}, J=3.2 \mathrm{~Hz}, \mathrm{C}\left(\mathrm{CH}_{3}\right)_{3}\right), 27.3$ $\left(\mathrm{CH}_{3}, \mathrm{vt}, \mathrm{J}=3.1 \mathrm{~Hz}, \mathrm{C}\left(\mathrm{CH}_{3}\right)_{3}\right)$.

\section{General Procedure for Determining Equilibrium Constants $K_{1}, K_{2}, K_{3}$ (Scheme 1)}

Samples were prepared as described below in benzene. Molarities of species were determined by carefully measuring the final volume of solution. Both ${ }^{1} \mathrm{H}$ and ${ }^{31} \mathrm{P}$ spectra were used to determine ratios of species. ${ }^{31} \mathrm{P}$ spectra were taken with a delay time of 15 seconds to ensure the integrals were accurate based on the $5 \times \mathrm{T} 1$ of $\mathbf{1 4 f}$.

\section{Reaction of (POCOP)Ir(H) $\left(\mathrm{C}_{6} \mathrm{H}_{5}\right)(12)$ and $p-\mathrm{CH}_{3} \mathrm{OC}_{6} \mathrm{H}_{4} \mathrm{NH}_{2}$ (11a)}

To a vial in the glovebox under argon, $9(0.088 \mathrm{mmol}, 55.35 \mathrm{mg}), \mathrm{NaO} t \mathrm{Bu}$ ( 0.8 equiv., 0.07 $\mathrm{mmol}, 6.0 \mathrm{mg}), 11 \mathrm{a}(0.041 \mathrm{mmol}, 5.1 \mathrm{mg}, 0.010 \mathrm{M})$, and benzene $(4 \mathrm{~mL})$ were added. The reaction mixture was allowed to stir for 1.5 hours. An aliquot was removed and analyzed by ${ }^{31} \mathrm{P}$ NMR. The equilibrium constants were calculated based on the concentrations of all the species in solution, $\left(K_{1}=1014, K_{2}=n / a\right)$. A second aliquot was removed after another hour to ensure reaction was at equilibrium. The reaction was repeated with an increase in the concentration of 11a to $0.05 \mathrm{M}\left(\mathrm{K}_{1}=1189, \mathrm{~K}_{2}=\mathrm{n} / \mathrm{a}\right)$. No 14a could be detected.

\section{Reaction of (POCOP) $\operatorname{Ir}(\mathrm{H})\left(\mathrm{C}_{6} \mathrm{H}_{5}\right)(12)$ and $p-\mathrm{CH}_{3} \mathrm{C}_{6} \mathrm{H}_{4} \mathrm{NH}_{2}(11 \mathrm{~b})$}

The general procedure for 11a was followed using 9 ( $0.069 \mathrm{mmol}, 43.45 \mathrm{mg}), \mathrm{NaO} t \mathrm{Bu}(0.9$ equiv., $0.062 \mathrm{mmol}, 6.0 \mathrm{mg}), \mathbf{1 1 b}(0.20 \mathrm{mmol}, 21.43 \mathrm{mg}, 0.050 \mathrm{M})$, and benzene $(4 \mathrm{~mL})$. 
$\left(\mathrm{K}_{1}=462, \mathrm{~K}_{2}=0.04\right)$. The reaction was repeated with an increase in the concentration of $11 \mathrm{~b}$ to $0.10 \mathrm{M}\left(\mathrm{K}_{1}=448, \mathrm{~K}_{2}=0.04\right)$.

\section{Reaction of (POCOP) Ir(H) $\left(\mathrm{C}_{6} \mathrm{H}_{5}\right)(12)$ and $\mathrm{C}_{6} \mathrm{H}_{5} \mathrm{NH}_{2}$ (11c)}

The general procedure for 11a was followed using $9(0.075 \mathrm{mmol}, 46.9 \mathrm{mg}), \mathrm{NaO} t \mathrm{Bu}(0.9$ equiv., $0.067 \mathrm{mmol}, 6.47 \mathrm{mg}), 11 \mathrm{c}(0.2 \mathrm{mmol}, 0.18 \mu \mathrm{L}, 0.050 \mathrm{M})$, and benzene $(4.0 \mathrm{~mL})$. $\left(\mathrm{K}_{1}=188, \mathrm{~K}_{2}=0.07\right)$. The reaction was repeated with an increase in the concentration of 11c to $0.10 \mathrm{M}\left(\mathrm{K}_{1}=189, \mathrm{~K}_{2}=0.08\right)$.

\section{Reaction of (POCOP)Ir(H)( $\left.\mathrm{C}_{6} \mathrm{H}_{5}\right)(12)$ and $p-\mathrm{ClC}_{6} \mathrm{H}_{4} \mathrm{NH}_{2}$ (11d)}

The general procedure for 11a was followed using 9 ( $0.074 \mathrm{mmol}, 46.15 \mathrm{mg}), \mathrm{NaO} t \mathrm{Bu}(0.9$ equiv., $0.066 \mathrm{mmol}, 6.4 \mathrm{mg}), 11 \mathrm{~d}(0.392 \mathrm{mmol}, 50 \mathrm{mg}, 0.10 \mathrm{M})$, and benzene $(4 \mathrm{~mL}) .\left(\mathrm{K}_{1}=\right.$ $\left.50, \mathrm{~K}_{2}=1\right)$. The reaction was repeated with an increase in the concentration of $11 \mathrm{~d}$ to 0.15 $\mathrm{mol} / \mathrm{L}\left(\mathrm{K}_{1}=60, \mathrm{~K}_{2}=1\right)$.

\section{Reaction of (POCOP)Ir(H) $\left(\mathrm{C}_{6} \mathrm{H}_{5}\right)(12)$ and $p-\mathrm{CF}_{3} \mathrm{C}_{6} \mathrm{H}_{4} \mathrm{NH}_{2}$ (11e)}

The general procedure for 11a was followed using $\mathbf{9}(0.138 \mathrm{mmol}, 86.6 \mathrm{mg}), \mathrm{NaO} t \mathrm{Bu}(0.9$ equiv., $0.124 \mathrm{mmol}, 11.9 \mathrm{mg}), 11 \mathrm{e}(0.08 \mathrm{mmol}, 12.9 \mathrm{mg}, 0.010 \mathrm{M})$, and benzene $(8 \mathrm{~mL})$. $\left(\mathrm{K}_{3}=272\right)$. The reaction was repeated with an increase in the concentration of $11 \mathrm{e}$ to $0.050 \mathrm{M}$ $\left(K_{3}=259\right)$. No 13e could be detected.

\section{Reaction of (POCOP) $\operatorname{Ir}(\mathrm{H})\left(\mathrm{C}_{6} \mathrm{H}_{5}\right)$ (12) and $\mathrm{C}_{6} \mathrm{~F}_{5} \mathrm{NH}_{2}$ (11f)}

The general procedure for 11a was followed using 9 (0.038 mmol, $23.75 \mathrm{mg}), \mathrm{NaO} t \mathrm{Bu}(0.9$ equiv., $0.0343 \mathrm{mmol}, 3.3 \mathrm{mg}), \mathbf{1 1 f}(0.0721 \mathrm{mmol}, 13.2 \mathrm{mg}, 0.009 \mathrm{M})$, and benzene $(8 \mathrm{~mL})$ was added. $\left(K_{3}=2010\right)$. The reaction was repeated with an increase in the concentration of $\mathbf{1 1 f}$ to $0.012 \mathrm{M}\left(\mathrm{K}_{3}=2300\right)$. No $\mathbf{1 3 f}$ could be detected.

\section{Reaction with (POCOP)Ir(H) $\left(\mathrm{C}_{6} \mathrm{H}_{5}\right)$ (12) and 3,5-( $\left.\mathrm{CF}_{3}\right)_{2} \mathrm{C}_{6} \mathrm{H}_{3} \mathrm{NH}_{2}$ (11g)}

The general procedure for 11a was followed using $9(0.158 \mathrm{mmol}, 99.05 \mathrm{mg}), \mathrm{NaO} / \mathrm{Bu}(0.9$ equiv., $0.142 \mathrm{mmol}, 13.65 \mathrm{mg}), \mathbf{1 1 g}(0.08 \mathrm{mmol}, 18 \mathrm{mg}, 0.010 \mathrm{M})$, and benzene $(8 \mathrm{~mL})$. $\left(\mathrm{K}_{3}\right.$ $=2700)$. The reaction was repeated with an increase in the concentration of $11 \mathrm{~g}$ to $0.050 \mathrm{M}$ $\left(K_{3}=2850\right)$. No $13 \mathrm{~g}$ could be detected.

\section{Low Temperature Oxidative Addition of $p$-Chloroaniline to 10}

To a screw cap NMR tube, $\mathbf{1 0}$ was generated by reaction of $\mathbf{9}(0.023 \mathrm{mmol}, 15 \mathrm{mg})$ with $\mathrm{NaO} t \mathrm{Bu}(0.023 \mathrm{mmol}, 2.3 \mathrm{mg})$ in $0.4 \mathrm{~mL}$ of toluene- $d_{8}$ at $100^{\circ} \mathrm{C}$ for $1 \mathrm{~h}$. The reaction mixture was cooled to $-78^{\circ} \mathrm{C}$ in a dry ice/acetone bath and a $0.1 \mathrm{~mL}$ of a $2.3 \mathrm{M}$ solution of $p$ chloroaniline $(0.23 \mathrm{mmol})$ was added via syringe. The reaction warmed in the NMR probe until the solution consisted solely of $\mathbf{1 3 c}$, after which the oxidative addition was monitored at $-12^{\circ} \mathrm{C}$. A data plot is included in supporting information.

\section{Kinetic Analysis of the Reductive Elimination Reactions of $14 \mathrm{e}-\mathrm{g}$}

In a screw cap NMR tube, $\mathbf{1 0}$ was generated by reaction of $\mathbf{9}(0.023 \mathrm{mmol}, 15 \mathrm{mg})$ with $\mathrm{NaO} t \mathrm{Bu}(0.023 \mathrm{mmol}, 2.3 \mathrm{mg})$ in $0.5 \mathrm{~mL}$ of toluene- $d_{8}$ at $100^{\circ} \mathrm{C}$ for $1 \mathrm{~h}$. Aniline $11 \mathrm{e}, \mathbf{f}$ or $\mathbf{g}$ were added to the solution of $\mathbf{1 0}$ and allowed to react for 45 minutes. The NMR tube was cooled to $-78^{\circ} \mathrm{C}$ in a dry ice/acetone bath, followed by addition of ethylene to the reaction mixture via syringe. The NMR tube was warmed to $9^{\circ} \mathrm{C}$ in the probe and the reductive elimination was monitored by ${ }^{1} \mathrm{H}$ NMR spectroscopy. A plot of kinetic data for $\mathbf{1 4 f}$ is included in supporting information. 


\section{Kinetic Analysis of the Dissociation of $\mathrm{H}_{2} \mathrm{NC}_{6} \mathrm{H}_{4}-p O M e$ (11a) from 13a}

$(\mathrm{POCOP}) \operatorname{Ir}(\mathrm{H})(\mathrm{Cl}) 9(10 \mathrm{mg}, 0.016 \mathrm{mmol}), \mathrm{NaO} t \mathrm{Bu}(1.7 \mathrm{mg}, 0.018 \mathrm{mmol})$, and toluene- $d_{8}$ $(0.4 \mathrm{~mL})$ were heated for $1 \mathrm{hr}$. at $100^{\circ} \mathrm{C}$ in a J. Young NMR tube to generate the tolyl hydride complexes 17. $p$-Methoxyaniline 11a ( $3.5 \mathrm{mg}, 0.024 \mathrm{mmol})$ and 1,3,5-trimethoxybenzene $(0.1$ $\mathrm{mL}, 0.11 \mathrm{M}$ solution in toluene- $d_{8}$ ) was added to the NMR tube. After freeze-pump-thawing the NMR sample, ethylene (10-20 equiv., $3.6^{-7.2} \mathrm{~mL}$ at $23^{\circ} \mathrm{C}$ ) was introduced via a gas tight syringe at liquid nitrogen temperature. The reaction was then monitored via low temperature NMR spectroscopy at $-8^{\circ} \mathrm{C}$. A plot of kinetic data is included in supporting information.

\section{$(\mathrm{POCOP}) \operatorname{Ir}(\mathrm{H})\left(\mathrm{NHC}_{6} \mathrm{~F}_{5}\right)(\mathrm{CO})(2 \mathrm{ff})$}

To a Schlenk flask, 9 (101 mg, $0.16 \mathrm{mmol}), \mathrm{NaO} t \mathrm{Bu}$ (17mg, 0.18mmol), 11f (33mg, 0.18 $\mathrm{mmol})$, and toluene $(5 \mathrm{~mL})$ were added and stirred at room temperature for 1 hour. The reaction mixture was cooled to $-78^{\circ} \mathrm{C}$ then $\mathrm{CO}$ was purged through the solution until the color lightened. The toluene was removed under vacuum and the product was extracted with pentane. The pentane was reduced under vacuum until the product began to precipitate. The pentane was then cooled to $-78^{\circ} \mathrm{C}$ and the precipitate was filtered and washed with cold pentane. (60 mg, $46 \%$ yield).

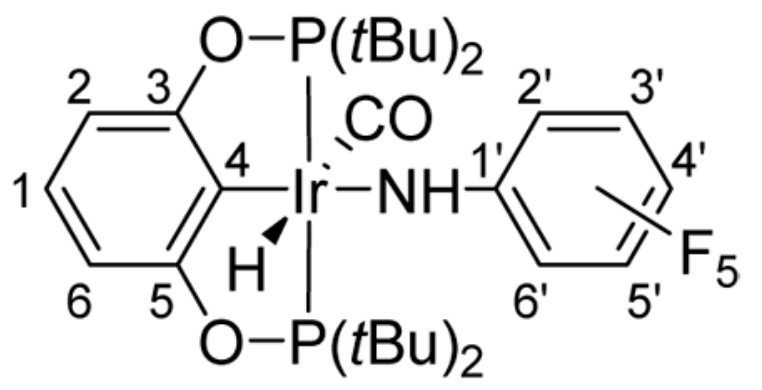

\section{$20 f$}

${ }^{1} \mathrm{H}$ NMR $\left(500 \mathrm{MHz}, \mathrm{C}_{6} \mathrm{D}_{6}\right): \delta 6.74\left(\mathrm{t},{ }^{3} J_{\mathrm{H}-\mathrm{H}}=8.0 \mathrm{~Hz}, 1 \mathrm{H}, 1-\mathrm{H}\right), 6.59\left(\mathrm{~d},{ }^{3} J_{\mathrm{H}-\mathrm{H}}=8.0 \mathrm{~Hz}, 2 \mathrm{H}\right.$, 2- and 6-H), $2.33(\mathrm{~s}, 1 \mathrm{H}, \mathrm{NH}), 1.20\left(\mathrm{vt}, J_{\mathrm{P}-\mathrm{H}}=7.7 \mathrm{~Hz}, 18 \mathrm{H}, \mathrm{P}(t \mathrm{Bu})_{2}\right), 1.11\left(\mathrm{vt}, J_{\mathrm{P}-\mathrm{H}}=7.3 \mathrm{~Hz}\right.$, $\left.18 \mathrm{H}, \mathrm{P}(t \mathrm{Bu})_{2}\right),-8.56\left(\mathrm{t}, J_{\mathrm{P}-\mathrm{H}}=17.9 \mathrm{~Hz}, 1 \mathrm{H}, \mathrm{Ir} H\right) .{ }^{31} \mathrm{P}\left\{{ }^{1} \mathrm{H}\right\} \mathrm{NMR}\left(162 \mathrm{MHz}, \mathrm{C}_{6} \mathrm{D}_{6}\right): \delta$ 57.6. ${ }^{19} \mathrm{~F}$ NMR (376.5 MHz, $\left.\mathrm{C}_{6} \mathrm{D}_{6}\right): \delta-163.3$ (bs), -169.0 (t), -186.7 (septet). ${ }^{13} \mathrm{C}\left\{{ }^{1} \mathrm{H}\right\}$ NMR $\left(125.8 \mathrm{MHz}, \mathrm{C}_{6} \mathrm{D}_{6}\right): \delta 179.4\left(\mathrm{C}_{\mathrm{q}}, C=\mathrm{O}\right), 163.8\left(\mathrm{C}_{\mathrm{q}}, \mathrm{vt}, J_{\mathrm{P}-\mathrm{C}}=3.7 \mathrm{~Hz}, \mathrm{C} 3\right.$ and $\left.\mathrm{C} 5\right), 140.4-135.8$ (m, $\mathrm{C}_{\mathrm{q}}, \mathrm{Ar}-\mathrm{F}_{5}$ : C2', C6', C3', C5', and C4'), $126.8(\mathrm{CH}, \mathrm{s}, \mathrm{C} 1), 106.0\left(\mathrm{CH}, \mathrm{t}, \mathrm{vt}, J_{\mathrm{P}-\mathrm{H}}=4.8 \mathrm{~Hz}\right.$, $\mathrm{C} 2$ and $\mathrm{C} 6), 43.0\left(\mathrm{Cq}, \mathrm{vt}, J_{\mathrm{P}-\mathrm{H}}=12.6 \mathrm{~Hz}, C\left(\mathrm{CH}_{3}\right)_{3}\right), 40.6\left(\mathrm{Cq}, \mathrm{vt}, J_{\mathrm{P}-\mathrm{H}}=11.4 \mathrm{~Hz}, C\left(\mathrm{CH}_{3}\right)_{3}\right)$, $28.1\left(\mathrm{CH}_{3}\right.$, vt, $\left.J_{\mathrm{P}-\mathrm{H}}=2.9 \mathrm{~Hz}, \mathrm{C}\left(\mathrm{CH}_{3}\right)_{3}\right), 27.2\left(\mathrm{CH}_{3}, \mathrm{vt}, J_{\mathrm{P}-\mathrm{H}}=2.4 \mathrm{~Hz}, \mathrm{C}\left(\mathrm{CH}_{3}\right)_{3}\right) . \mathrm{C} 4$ and C1' not observed due to low intensity. IR $\left(\mathrm{C}_{6} \mathrm{D}_{6}\right): 2022 \mathrm{~cm}^{-1}$. Elemental analysis calculated for $\mathrm{C}_{29} \mathrm{H}_{41} \mathrm{O}_{3} \mathrm{P}_{2} \mathrm{~N}_{1} \mathrm{~F} 5 \mathrm{Ir}$ (800.80): C: 43.50, H: 5.16, N: 1.75. Found: C: 43.70, H: 5.25, N: 1.71.

\section{Reductive Elimination of $p$-trifluoromethylaniline from (POCOP) $\operatorname{Ir}(\mathrm{H})(\mathrm{CO})\left(\mathrm{NHC}_{6} \mathrm{H}_{4}-p \mathrm{CF}_{3}\right) 2 \mathrm{ee}$}

In a J. Young NMR tube, tolyl complexes 17 were generated by heating the reaction mixture of (POCOP) $\operatorname{Ir}(\mathrm{H})(\mathrm{Cl}) 9(15 \mathrm{mg}, 0.024 \mathrm{mmol}), \mathrm{NaO} t \mathrm{Bu}(2.3 \mathrm{mg}, 0.024 \mathrm{mmol})$, and $0.5 \mathrm{~mL}$ of toluene- $d_{8}$ for 1 hour at $100^{\circ} \mathrm{C}$. The reaction mixture was cooled to room temperature. The addition of $p-\mathrm{CF}_{3}$-aniline 11e $(6.0 \mu \mathrm{L}, 0.048 \mathrm{mmol})$ formed complex 14e. After freeze-pumpthawing the reaction mixture, a gastight syringe was used to add sufficient $\mathrm{CO}$ at liquid $\mathrm{N}_{2}$ temperature to generate pressures of 1,2 , and 3 atmospheres of $\mathrm{CO}$ in the head space at $25^{\circ} \mathrm{C}$. The reaction was monitored at $63^{\circ} \mathrm{C}$ by ${ }^{1} \mathrm{H}$ NMR spectroscopy. 


\section{Procedure for Monitoring Reaction of Benzamide Complex 22a with $\mathrm{PPh}_{3}$}

A stock solution of (POCOP) $\operatorname{Ir}(\mathrm{H})(\mathrm{NH}(\mathrm{CO}) \mathrm{Ar})$ was prepared in the glovebox under Ar by stirring (POCOP) $\operatorname{Ir}(\mathrm{H})(\mathrm{Cl}) 9$ (112.7 mg, $0.18 \mathrm{mmol}), \mathrm{NaO} t \mathrm{Bu}(20.7 \mathrm{mg}, 0.22 \mathrm{mmol})$, benzamide $21 \mathrm{a}(26.2 \mathrm{mg}, 0.22 \mathrm{mmol})$, and toluene- $d_{8}(3.0 \mathrm{~mL})$ until the color of the solution turned pale orange, ca. 30 minutes. The excess benzamide and $\mathrm{NaO} t \mathrm{Bu}$ were filtered out through a 0.02 micron syringe filter. The concentration of the stock solution $(0.063 \mathrm{M})$ was measured via ${ }^{1} \mathrm{H}$ NMR using $2.0 \mu \mathrm{L}$ of mesitylene as a standard. Aliquots $(0.5 \mathrm{~mL})$ of the stock solution were added to three $\mathrm{J}$. Young NMR tubes containing known amounts of $\mathrm{PPh}_{3}(0.147$ $\mathrm{mmol}, 0.294 \mathrm{mmol}, 0.588 \mathrm{mmol})$. The NMR tubes were heated to $100^{\circ} \mathrm{C}$ for three days, after which the reaction was stopped by placing the NMR tubes in cold water. The $\mathrm{K}_{\mathrm{eq}}$ was calculated by measuring the ratios of $22 \mathrm{a}$ and 26 by ${ }^{31} \mathrm{P} N M R . \mathrm{K}_{\mathrm{eq}}=0.18$.

\section{Procedure for Monitoring Reaction of Benzamide Complexes 22b with $\mathrm{PPh}_{3}$}

A stock solutions was prepared using 9 ( $92.5 \mathrm{mg}, 0.148 \mathrm{mmol}), \mathrm{NaO} t \mathrm{Bu}(71.0 \mathrm{mg}, 0.74 \mathrm{mmol})$, $22 \mathbf{b}(161.6 \mathrm{mg}, 0.74 \mathrm{mmol})$, and toluene- $d_{8}(6.0 \mathrm{~mL})$. Aliquots of the stock solution $(0.6 \mathrm{~mL}$, $0.021 \mathrm{M})$ were placed in three J. Young tubes with known amounts of $\mathrm{PPh}_{3}(0.126 \mathrm{mmol}, 0.252$ $\mathrm{mmol}, 0.378 \mathrm{mmol})$. The reaction was heated to $100^{\circ} \mathrm{C}$ overnight, after which the reaction was stopped by placing the NMR tubes in cold water. The the $\mathrm{K}_{\mathrm{eq}}$ was calculated by measuring the ratios of $\mathbf{2 2 b}$ and 26 by ${ }^{31} \mathrm{P}$ NMR. $\mathrm{K}_{\mathrm{eq}}=0.067$.

\section{(POCOP)Ir( $\left.\mathrm{PPh}_{3}\right)(\mathbf{2 4})$}

In a Schlenk flask 9 (104 mg, $0.166 \mathrm{mmol}), \mathrm{NaO} t \mathrm{Bu}(17.6 \mathrm{mg}, 0.183 \mathrm{mmol}), \mathrm{PPh}_{3}(46 \mathrm{mg}$, $0.174 \mathrm{mmol})$, and toluene $(10 \mathrm{~mL})$ were combined and stirred overnight. Toluene was removed under vacuum until the product precipitated. The product was filtered, washed with cold toluene, and dried under vacuum to yield an orange solid ( $74 \mathrm{mg}, 52 \%$ yield).

${ }^{1} \mathrm{H}$ NMR (500 MHz, $\left.\mathrm{C}_{6} \mathrm{D}_{6}\right): \delta 8.06\left(\mathrm{t}, 6 \mathrm{H}, \mathrm{PPh}_{3}\right), 6.9-7.1$ (m, $12 \mathrm{H}$, aromatic protons), 1.072 $\left(\mathrm{vt}, J_{\mathrm{P}-\mathrm{H}}=6.8 \mathrm{~Hz}, 36 \mathrm{H}, \mathrm{P}(t \mathrm{Bu})_{2}\right) .{ }^{31} \mathrm{P}\left\{{ }^{1} \mathrm{H}\right\} \mathrm{NMR}\left(162 \mathrm{MHz}, \mathrm{C}_{6} \mathrm{D}_{6}\right): \delta 181.2\left(\mathrm{~d}, J_{\mathrm{P}-\mathrm{P}}=5.2 \mathrm{~Hz}\right)$, $15.8\left(\mathrm{t}, J_{\mathrm{P}-\mathrm{P}}=5.5 \mathrm{~Hz}\right) .{ }^{13} \mathrm{C}\left\{{ }^{1} \mathrm{H}\right\} \mathrm{NMR}\left(100.6 \mathrm{MHz}, \mathrm{C}_{6} \mathrm{D}_{6}\right): \delta 166.4\left(\mathrm{C}_{\mathrm{q}}, \mathrm{vt}, J_{\mathrm{P}-\mathrm{C}}=6.5 \mathrm{~Hz}, \mathrm{C} 3\right.$ and C5), 141.5, 135.7, 133.7, 129, 127.0, 125.7 (CH, s, C1), 102.7 (CH, t, vt, C2 and C6), 41.0 $\left(\mathrm{Cq}, \mathrm{vt}, J_{\mathrm{P}-\mathrm{H}}=11.6 \mathrm{~Hz}, \mathrm{C}\left(\mathrm{CH}_{3}\right)_{3}\right), 28.7\left(\mathrm{CH}_{3}\right.$, s). Elemental analysis calculated for $\mathrm{C}_{40} \mathrm{H}_{54} \mathrm{O}_{2} \mathrm{P}_{3} \mathrm{Ir}$ (851.99): C: $56.39, \mathrm{H}: 6.39$. Found: C: $56.19, \mathrm{H}: 6.37$. Crystallographic data is included in the supporting information.

\section{Kinetic Analysis of the Reductive Elimination of Benzamide 22a}

A stock solution $(0.06 \mathrm{M})$ of $(\mathrm{POCOP}) \operatorname{Ir}(\mathrm{H})\left(\mathrm{NH}(\mathrm{CO}) \mathrm{C}_{6} \mathrm{H}_{5}\right)$ 23a was prepared under $\mathrm{Ar}$ by stirring (POCOP) $\mathrm{Ir}(\mathrm{H})(\mathrm{Cl}) 9$ (75.1 mg, $0.12 \mathrm{mmol}), \mathrm{NaO} t \mathrm{Bu}(12.7 \mathrm{mg}, 0.132 \mathrm{mmol})$, benzamide $22 \mathrm{a}(16.0 \mathrm{mg}, 0.132 \mathrm{mmol})$, and toluene- $d_{8}(2 \mathrm{~mL})$ until the color of the solution turned pale orange. The excess benzamide and $\mathrm{NaO} t \mathrm{Bu}$ were filtered out through a 0.02 micron syringe filter. To a screw cap NMR tube, 10 equiv. of 22a (15 mg, $0.124 \mathrm{mmol}), 10$ equiv. of $\mathrm{PPh}_{3}(32.5 \mathrm{mg}, 0.124 \mathrm{mmol})$, the stock solution of $23 \mathbf{a}(0.21 \mathrm{~mL}, 0.06 \mathrm{M})$, and toluene- $d_{8}(0.4$ $\mathrm{mL}$ ) were added. The reaction was heated to $100^{\circ} \mathrm{C}$ in the NMR probe and over time the disappearance of 23a signals were monitored via ${ }^{1} \mathrm{H}$ NMR. A plot of kinetic data is included in supporting information.

\section{(POCOP)Ir(H)(NH(CO)(Ph) (22a)}

(POCOP)Ir(H)(Cl) (9) (100 mg, $0.16 \mathrm{mmol}), \mathrm{NaO} t \mathrm{Bu}(18.4 \mathrm{mg}, 0.192 \mathrm{mmol}), \mathrm{H}_{2} \mathrm{~N}(\mathrm{CO})$ $\mathrm{C}_{6} \mathrm{H}_{5}$ (21a) $(23.2 \mathrm{mg}, 0.192 \mathrm{mmol})$, and $5.0 \mathrm{~mL}$ of benzene were added to a Schlenk flask and allowed to stir for 1.5 hours until color changed to a light orange color. The solution was filtered though a 0.2 micron syringe filter, and the benzene was sublimed at $0^{\circ} \mathrm{C}$ to yield a yellow/ orange colored solid $(71.6 \mathrm{mg}, 63 \%$ yield). 


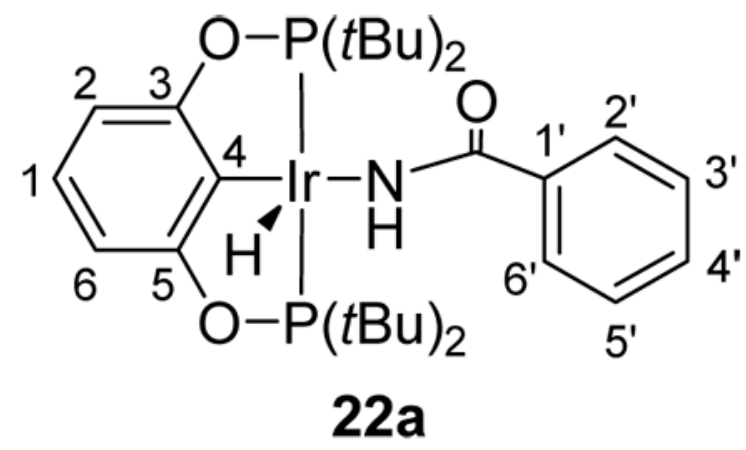

${ }^{1} \mathrm{H}$ NMR (500 MHz, $\left.\mathrm{C}_{6} \mathrm{D}_{6}\right): \delta$ 7.64-7.62 (m, 2H, 2'- and 6'-H), 7.12-7.07 (m, 3H, 3'-, 4', and 5'-H), 6.87-6.79 (m, 3H, 1-, 2-, and 3-H), $5.90(\mathrm{bs}, 1 \mathrm{H}, \mathrm{NH}), 1.40\left(\mathrm{vt}, J_{\mathrm{P}-\mathrm{H}}=6.9 \mathrm{~Hz}, 18 \mathrm{H}, \mathrm{P}\right.$ $\left.(t \mathrm{Bu})_{2}\right), 1.28\left(\mathrm{vt}, J_{\mathrm{P}-\mathrm{H}}=7.0 \mathrm{~Hz}, 18 \mathrm{H}, \mathrm{P}(t \mathrm{Bu})_{2}\right),-30.25\left(\mathrm{t}, J_{\mathrm{P}-\mathrm{H}}=13.2 \mathrm{~Hz}, 1 \mathrm{H}, \operatorname{Ir} H\right) .{ }^{31} \mathrm{P}\left\{{ }^{1} \mathrm{H}\right\}$ NMR (162 MHz, $\left.\mathrm{C}_{6} \mathrm{D}_{6}\right): \delta 164.2 .{ }^{13} \mathrm{C}\left\{{ }^{1} \mathrm{H}\right\}$ NMR $\left(125.8 \mathrm{MHz}, \mathrm{C}_{6} \mathrm{D}_{6}\right): \delta 176.4\left(\mathrm{C}_{\mathrm{q}}, \mathrm{t}, J_{\mathrm{P}-\mathrm{C}}=\right.$ $1.3 \mathrm{~Hz}, \mathrm{CO}), 166.6\left(\mathrm{C}_{\mathrm{q}}\right.$, vt, $J_{\mathrm{P}-\mathrm{C}}=6.0 \mathrm{~Hz}, \mathrm{C} 3$ and $\left.\mathrm{C} 5\right), 138.4\left(\mathrm{C}_{\mathrm{q}}, \mathrm{s}, \mathrm{C} 1{ }^{\prime}\right), 130.1\left(\mathrm{CH}, \mathrm{s}, \mathrm{C} 4{ }^{\prime}\right)$, $128.3\left(\mathrm{CH}, \mathrm{s}, \mathrm{C} 3{ }^{\prime}\right.$ and $\left.\mathrm{C}^{\prime}\right), 126.3\left(\mathrm{CH}, \mathrm{s}, \mathrm{C} 2\right.$ ' and $\left.\mathrm{C}^{\prime}\right), 124.1$ (CH, s, C1), $118.5(\mathrm{C} 4), 104.5$ $\left(\mathrm{CH}, \mathrm{t}, J_{\mathrm{P}-\mathrm{C}}=5.4 \mathrm{~Hz}, \mathrm{C} 2\right.$ and C6), $42.5\left(\mathrm{Cq}, \mathrm{vt}, J_{\mathrm{P}-\mathrm{H}}=12.0 \mathrm{~Hz}, C\left(\mathrm{CH}_{3}\right)_{3}\right), 39.9\left(\mathrm{Cq}, \mathrm{vt}, J_{\mathrm{P}-\mathrm{H}}\right.$ $\left.=11.8 \mathrm{~Hz}, C\left(\mathrm{CH}_{3}\right)_{3}\right), 28.8\left(\mathrm{CH}_{3}, \mathrm{vt}, J_{\mathrm{P}-\mathrm{H}}=3.3 \mathrm{~Hz}, \mathrm{C}\left(\mathrm{CH}_{3}\right)_{3}\right), 27.6\left(\mathrm{CH}_{3}\right.$, bvt, $J_{\mathrm{P}-\mathrm{H}}=2.2 \mathrm{~Hz}$, $\left.\mathrm{C}\left(\mathrm{CH}_{3}\right)_{3}\right)$. Elemental analysis calculated for $\mathrm{C}_{29} \mathrm{H}_{46} \mathrm{O}_{3} \mathrm{P}_{2} \mathrm{~N}_{1} \operatorname{Ir}$ (710.85): C: 49.00, H: 6.52, N: 1.97. Found: C: $49.22, \mathrm{H}: 6.59, \mathrm{~N}: 2.00$.

(POCOP) Ir(H)(NH(CO) $\left(\mathrm{C}_{6} \mathrm{~F}_{5}\right)(22 \mathrm{~b})$

(POCOP) $\mathrm{Ir}(\mathrm{H})(\mathrm{Cl})(\mathbf{9})(100 \mathrm{mg}, 0.16 \mathrm{mmol}), \mathrm{NaO} t \mathrm{Bu}(18.4 \mathrm{mg}, 0.192 \mathrm{mmol}), \mathrm{H}_{2} \mathrm{~N}(\mathrm{CO})$ $\mathrm{C}_{6} \mathrm{~F}_{5}$ (21b) $(40.5 \mathrm{mg}, 0.192 \mathrm{mmol})$, and $5.0 \mathrm{~mL}$ of benzene were added to a Schlenk flask and allowed to stir for 1.5 hours until the color changed to a light orange color. The solution was filtered though a 0.2 micron syringe filter, and the benzene was sublimed at $0^{\circ} \mathrm{C}$ to yield a yellow/orange colored solid (101.6 mg, 79\% yield).

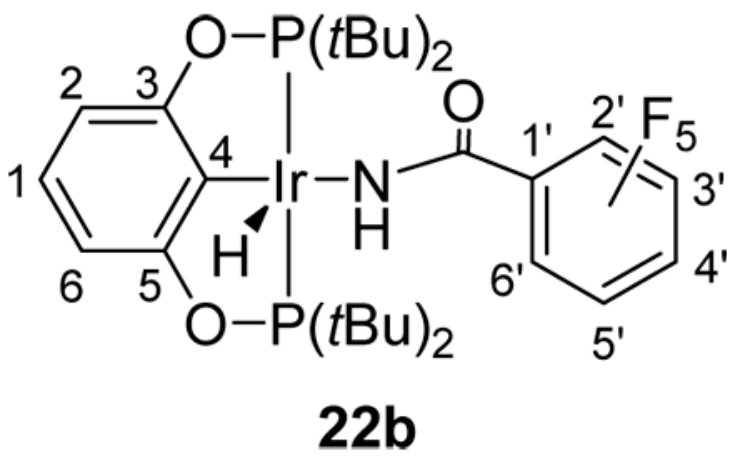

${ }^{1} \mathrm{H}$ NMR (500 MHz, $\left.\mathrm{C}_{6} \mathrm{D}_{6}\right): \delta 6.87-6.78(\mathrm{~m}, 3 \mathrm{H}, 1-, 2-, 6-\mathrm{H}), 5.49$ (bs, $\left.1 \mathrm{H}, \mathrm{Ni}\right), 1.44$ (vt, $\left.J_{\mathrm{P}-\mathrm{H}}=7.0 \mathrm{~Hz}, 18 \mathrm{H}, \mathrm{P}(t \mathrm{Bu})_{2}\right), 1.22\left(\mathrm{vt}, J_{\mathrm{P}-\mathrm{H}}=7.0 \mathrm{~Hz}, 18 \mathrm{H}, \mathrm{P}(t \mathrm{Bu})_{2}\right),-35.72\left(\mathrm{t}, J_{\mathrm{P}-\mathrm{H}}=13.0\right.$ $\mathrm{Hz}, 1 \mathrm{H}, \operatorname{Ir} H^{19} \mathrm{~F}$ NMR $\left(376.5 \mathrm{MHz}, \mathrm{C}_{6} \mathrm{D}_{6}\right): \delta-141.76(\mathrm{~m}),-155.25(\mathrm{~m}),-166.61(\mathrm{~m}) .{ }^{13} \mathrm{C}$ $\left\{{ }^{1} \mathrm{H}\right\} \mathrm{NMR}\left(125.8 \mathrm{MHz}, \mathrm{C}_{6} \mathrm{D}_{6}\right): \delta 167.2\left(\mathrm{C}_{\mathrm{q}}, \mathrm{vt}, J_{\mathrm{P}-\mathrm{C}}=5.8 \mathrm{~Hz}, \mathrm{C} 3\right.$ and $\left.\mathrm{C} 5\right), 163.0\left(\mathrm{C}_{\mathrm{q}}, \mathrm{s}\right.$, $C \mathrm{O}), 144.5\left(\mathrm{C}_{\mathrm{q}}, \mathrm{dm},{ }^{1} J_{\mathrm{F}-\mathrm{C}}=241.8 \mathrm{~Hz}, \mathrm{C} 2\right.$ ' and $\left.\mathrm{C}^{\prime}\right), 141.1\left(\mathrm{C}_{\mathrm{q}}, \mathrm{dm},{ }^{1} J_{\mathrm{F}-\mathrm{C}}=254.3 \mathrm{~Hz}, \mathrm{C} 4{ }^{\prime}\right)$, $137.7\left(\mathrm{C}_{\mathrm{q}}, \mathrm{dm},{ }^{1} J_{\mathrm{F}-\mathrm{C}}=252.0 \mathrm{~Hz}, \mathrm{C}^{\prime}\right.$ and $\left.\mathrm{C}^{\prime}\right), 125.4(\mathrm{CH}, \mathrm{s}, \mathrm{C} 1), 119.9\left(\mathrm{C}_{\mathrm{q}}, \mathrm{m}, \mathrm{C} 4\right), 116.2$ $\left(\mathrm{C}_{\mathrm{q}}, \mathrm{m}, \mathrm{C} 1^{\prime}\right), 104.7\left(\mathrm{CH}, \mathrm{t}, \mathrm{vt}, J_{\mathrm{P}-\mathrm{H}}=5.3 \mathrm{~Hz}, \mathrm{C} 2\right.$ and C6), $42.8\left(\mathrm{Cq}, \mathrm{vt}, J_{\mathrm{P}-\mathrm{H}}=12.1 \mathrm{~Hz}, C\right.$ $\left.\left(\mathrm{CH}_{3}\right)_{3}\right), 39.8\left(\mathrm{Cq}, \mathrm{vt}, J_{\mathrm{P}-\mathrm{H}}=12.1 \mathrm{~Hz}, \mathrm{C}\left(\mathrm{CH}_{3}\right)_{3}\right), 28.3\left(\mathrm{CH}_{3}, \mathrm{vt}, J_{\mathrm{P}-\mathrm{H}}=3.3 \mathrm{~Hz}, \mathrm{C}\left(\mathrm{CH}_{3}\right)_{3}\right), 27.6$ $\left(\mathrm{CH}_{3}, \mathrm{vt}, J_{\mathrm{P}-\mathrm{H}}=3.1 \mathrm{~Hz}, \mathrm{C}\left(\mathrm{CH}_{3}\right)_{3}\right)$. Elemental analysis calculated for $\mathrm{C}_{29} \mathrm{H}_{41} \mathrm{O}_{3} \mathrm{P}_{2} \mathrm{~N}_{1} \mathrm{~F}_{5} \mathrm{Ir}$ (800.80): C: 43.50, H: 5.16, N: 1.75. Found: C: 43.70, H: 5.25, N: 1.71. 


\section{Supplementary Material}

Refer to Web version on PubMed Central for supplementary material.

\section{Acknowledgment}

We gratefully acknowledge funding by the National Institute of Health (grant No. GM 28938).

\section{REFERENCES}

1. Janowicz AH, Bergman RG. J. Am. Chem. Soc 1982;104:352.

2. Jones WD, Feher F. Organometallics 1983;2:562.

3. Hoyano JK, McMaster AD, Graham WAG. J. Am. Chem. Soc 1983;105:7190.

4. Shilov AE, Shul'pin GB. Chem. Rev 1997;97:2879. [PubMed: 11851481]

5. Arndtsen BA, Bergman RG, Mobley TA, Peterson TH. Acc. Chem. Res 1995;28:154.

6. Crabtree RH. J. Chem. Soc., Dalton Trans 2001:2951.

7. Crabtree RH. Dalton Transactions 2003:3985.

8. Lersch M, Tilset M. Chem. Rev 2005;105:2471. [PubMed: 15941220]

9. Jun C-H, Lee JH. Pure Appl. Chem 2004;76:577.

10. Ishiyama T. Kagaku to Kogyo (Tokyo) 2003;56:1237.

11. Kakiuchi F, Chatani N. Adv. Synth. Catal 2003;345:1077.

12. Labinger JA, Bercaw JE. Nature (London) 2002;417:507. [PubMed: 12037558]

13. Hartwig JF, Andersen RA, Bergman RG. Organometallics 1991;10:1875.

14. Glueck DS, Winslow LJN, Bergman RG. Organometallics 1991;10:1462.

15. Bryndza HE, Tam W. Chem. Rev 1988;88:1163.

16. Fulton JR, Holland AW, Fox DJ, Bergman RG. Acc. Chem. Res 2002;35:44. [PubMed: 11790088]

17. Utsunomiya M, Hartwig JF. J. Am. Chem. Soc 2004;126:2702. [PubMed: 14995178]

18. Hartwig JF. Pure Appl. Chem 2004;76:507.

19. Beller M, Breindl C, Eichberger M, Hartung CG, Seayad J, Thiel OR, Tillack A, Trauthwein H. Synlett 2002:1579.

20. Utsunomiya M, Kuwano R, Kawatsura M, Hartwig JF. J. Am. Chem. Soc 2003;125:5608. [PubMed: 12733880]

21. Uchimaru Y. Chem. Comm 1999:1133.

22. Casalnuovo AL, Calabrese JC, Milstein D. J. Am. Chem. Soc 1988;110:6738.

23. Ladipo FT, Merola JS. Inorg. Chem 1990;29:4172.

24. Liu F, Pak EB, Singh B, Jensen CM, Goldman AS. J. Am. Chem. Soc 1999;121:4086.

25. Kanzelberger M, Singh B, Czerw M, Krogh-Jespersen K, Goldman AS. J. Am Chem. Soc 2000;122:11017.

26. Zhang X, Fried A, Knapp S, Goldman AS. Chem. Comm 2003:2060. [PubMed: 12934911]

27. Kanzelberger M, Zhang X, Emge TJ, Goldman AS, Zhao J, Incarvito C, Hartwig JF. J. Am. Chem. Soc 2003;125:13644. [PubMed: 14599186]

28. Zhao J, Goldman AS, Hartwig JF. Science (Washington, DC, United States) 2005;307:1080.

29. Goettker-Schnetmann I, Brookhart M. J. Am. Chem. Soc 2004;126:9330. [PubMed: 15281824]

30. Goettker-Schnetmann I, White P, Brookhart M. J. Am. Chem. Soc 2004;126:1804. [PubMed: 14871112]

31. Goettker-Schnetmann I, White PS, Brookhart M. Organometallics 2004;23:1766.

32. Crabtree RH. Science (Washington, D. C.) 1998;282:2000.

33. Krogh-Jespersen K, Czerw M, Zhu K, Singh B, Kanzelberger M, Darji N, Achord PD, Renkema KB, Goldman AS. J. Am. Chem. Soc 2002;124:10797. [PubMed: 12207536]

34. Crabtree, RH. The Organometallic Chemistry of the Transition Metals. Third ed.. New York, NY: John Wiley and Sons, Inc; 2001.

Organometallics. Author manuscript; available in PMC 2008 December 11. 
35. Caulton KG. New J. Chem 1994;18:25.

36. Holland PL, Andersen RA, Bergman RG. Comments Inorg. Chem 1999;21:115.

37. Holland PL, Andersen RA, Bergman RG, Huang J, Nolan SP. J. Am. Chem. Soc 1997;119:12800.

38. Formed by reaction of in situ generated $\mathbf{1 4 f}$ followed by addition of $\mathrm{PMe}_{3}$ at $-40^{\circ} \mathrm{C}$. Key NMR resonances include ${ }^{1} \mathrm{H}$ NMR $\left(400 \mathrm{MHz}, \mathrm{C}_{7} \mathrm{D}_{8}\right): \delta-11.9\left(\mathrm{dt}, \mathrm{Ir}-H, J_{P-H}=149.1 \mathrm{~Hz}\right.$ (trans), J-H $=$ $23.4 \mathrm{~Hz}$ (cis), and ${ }^{31} \mathrm{P}\left(162 \mathrm{MHz}, \mathrm{C}_{7} \mathrm{D}_{8}\right): \delta 169.6(\mathrm{~m}, 2 \mathrm{P}),-57.1(\mathrm{~m}, 1 \mathrm{P})$.

39 . The stability of the aryl hydride complex can be dramatically altered by incorporation of fluorine substituents in the aromatic ring. In preliminary experiments we have shown that reaction of (POCOP)Ir, 10, with 2,3,5,6-tetrafluoroaniline yields solely the C-H activation product (POCOP)Ir $(\mathrm{H})\left(\mathrm{C}_{6} \mathrm{~F}_{4} \mathrm{NH}_{2}\right)$. Strengthening of the Re-aryl bond through fluorination Of the aryl ring has been well-documented in earlier studies Perutz by et. al. (Chem. Commun., 2003, 490)

40. Crumpton-Bregel DM, Goldberg KI. J. Am. Chem. Soc 2003;125:9442. [PubMed: 12889975]

41. Chin CS, Chong D, Lee S, Park YJ. Organometallics 2000;19:4043.

42. Cooper AC, Huffman JC, Caulton KG. Inorg. Chim. Acta 1998;270:261.

43. Tellers DM, Ritter JCM, Bergman RG. Inorg. Chem 1999;38:4810. [PubMed: 11671210]

44. Baghurst DR, Mingos DMP, Watson MJ. J. Organomet. Chem 1989;368:C43.

Organometallics. Author manuscript; available in PMC 2008 December 11. 


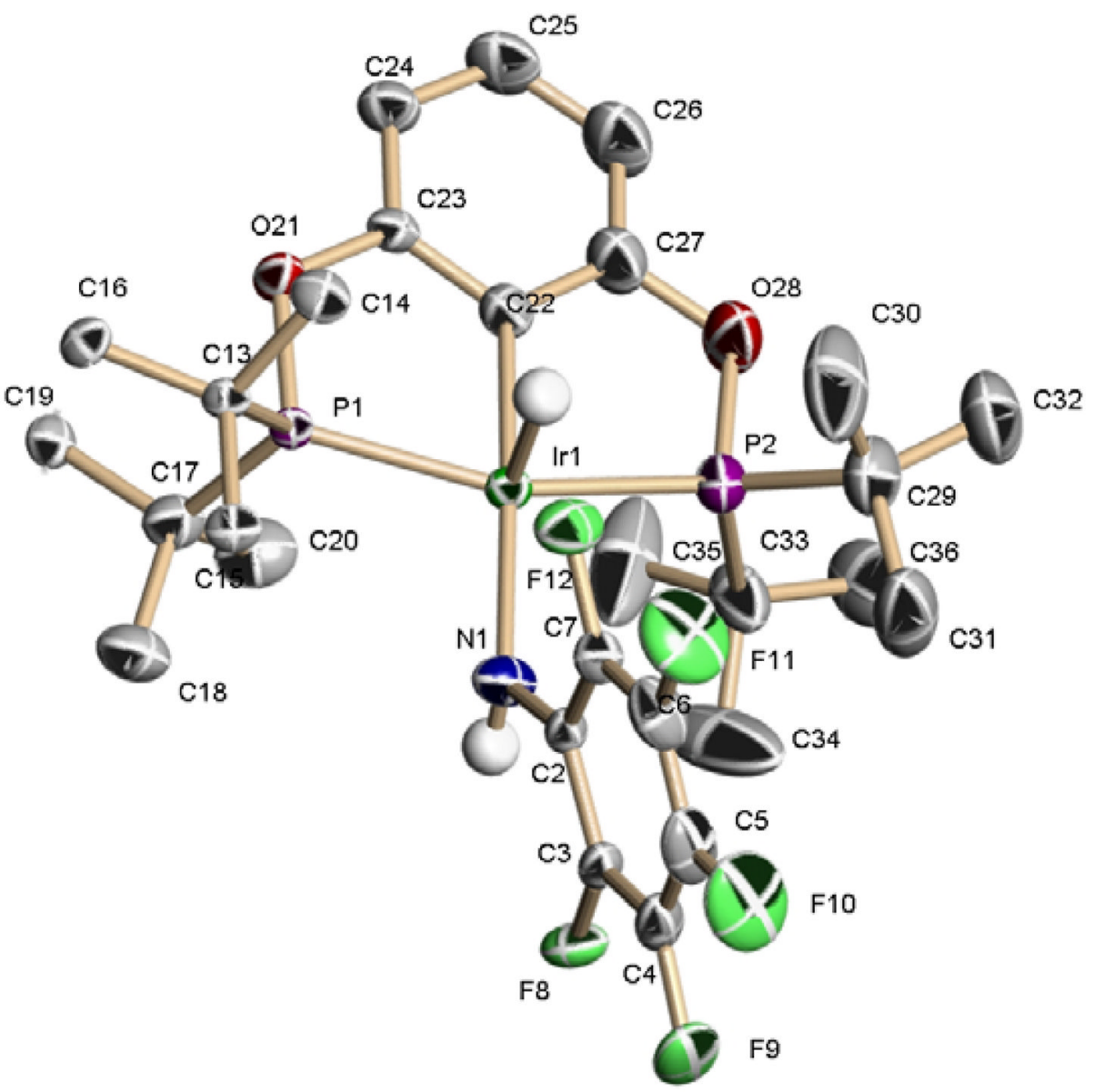

Figure 1.

ORTEP diagram of 14f. Only the hydrogens on iridium and nitrogen are shown for clarity. Key bond distances $(\AA)$ and bond angles (degrees): $\operatorname{Ir}(1)-\mathrm{N}(1) 2.145 \AA, \mathrm{N}(1)-\mathrm{C}(2) 1.348 \AA$, $\operatorname{Ir}(1)-\mathrm{C}(22) 2.013 \AA, \operatorname{Ir}(1)-\mathrm{P}(1) 2.294 \AA, \operatorname{Ir}(1)-\mathrm{P}(2) 2.309 \AA, \mathrm{C}(22)-\operatorname{Ir}(1)-\mathrm{N}(1) 177.32^{\circ}, \mathrm{P}(1)-$ $\operatorname{Ir}(1)-\mathrm{N}(1) 99.20^{\circ}, \mathrm{P}(2)-\operatorname{Ir}(1)-\mathrm{N}(1) 101.42^{\circ}, \operatorname{Ir}(1)-\mathrm{N}(1)-\mathrm{C}(2)-\mathrm{C}(7) 32.5^{\circ}, \mathrm{H}-\operatorname{Ir}(1)-\mathrm{N}(1)-\mathrm{H}$ $177.31^{\circ}$ 

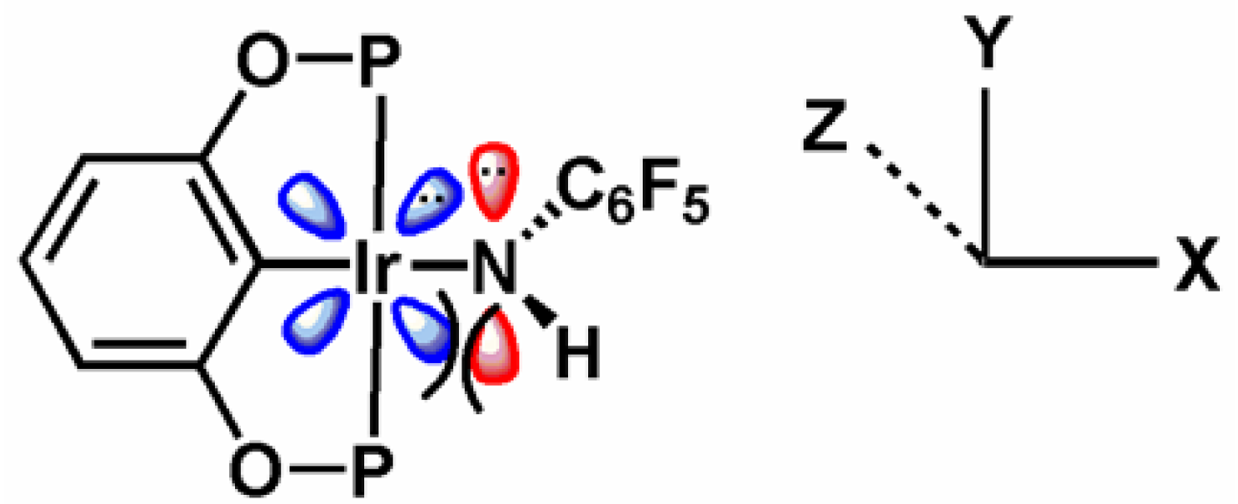

Figure 2.

The destabilizing interaction between the filled $\mathrm{N}-\pi$ orbital $\left(p_{y}\right)$ and the filled $\operatorname{Ir} d_{x y}$ orbital. (Apical hydride not shown) 

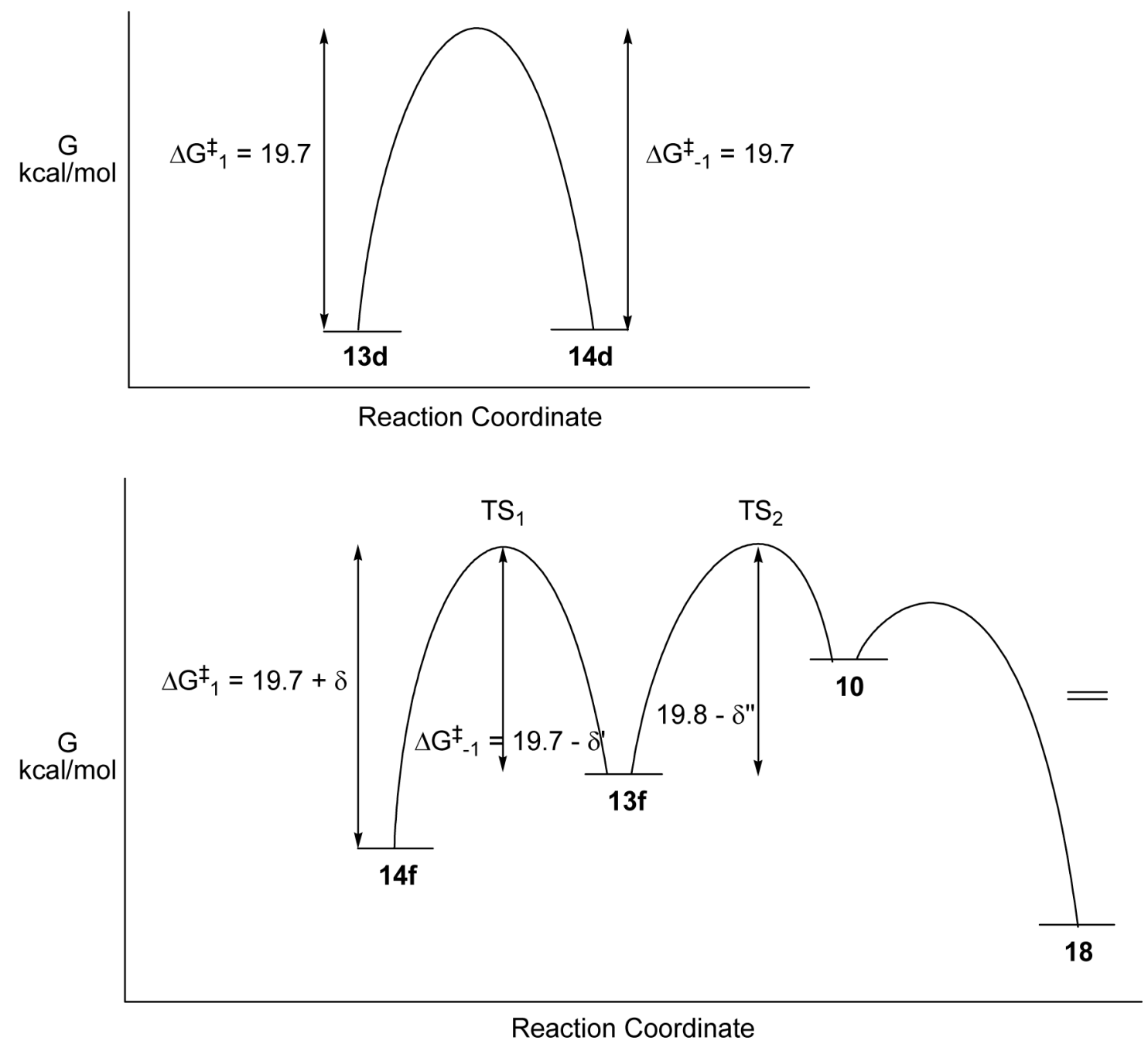

Figure 3.

Reaction coordinate diagram for interconversion of $\mathbf{1 3 d}$ and $\mathbf{1 4 d}$ and conversion of $\mathbf{1 4 f}$ to 18. 


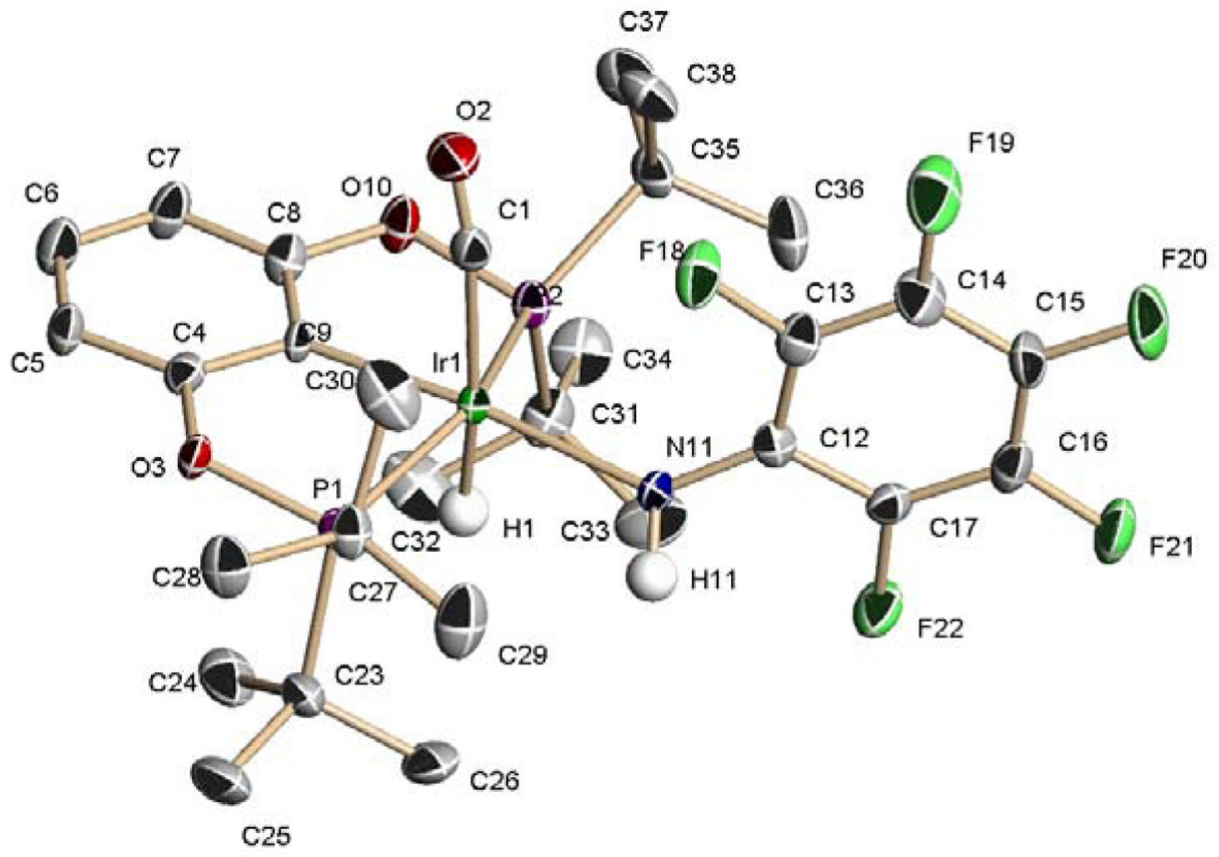

Figure 4.

ORTEP Diagram of (POCOP) $\operatorname{Ir}(\mathrm{H})(\mathrm{CO})\left(\mathrm{NHC}_{6} \mathrm{~F}_{5}\right)(\mathbf{2 0 f})$. Only the hydrogens on iridium and nitrogen are shown for clarity. Key bond distances $(\AA)$ and bond angles (degrees): $\operatorname{Ir}(1)-\mathrm{N}(11)$ $2.168 \AA, \mathrm{N}(11)-\mathrm{C}(12) 1.361 \AA, \operatorname{Ir}(1)-\mathrm{C}(9) 2.046 \AA, \operatorname{Ir}(1)-\mathrm{P}(1) 2.337 \AA, \operatorname{Ir}(1)-\mathrm{P}(2) 2.329 \AA$, $\mathrm{H}(1)-\operatorname{Ir}(1)-\mathrm{N}(11)-\mathrm{H}(11) 42.22^{\circ}, \mathrm{C}(9)-\operatorname{Ir}(1)-\mathrm{N}(11) 173.3^{\circ}, \mathrm{P}(1)-\operatorname{Ir}(1)-\mathrm{N}(11) 98.82^{\circ}, \mathrm{P}(2)-\mathrm{Ir}$ (1) $-\mathrm{N}(11) 100.97^{\circ}, \operatorname{Ir}(1)-\mathrm{N}(11)-\mathrm{C}(12)-\mathrm{C}(13) 139.79^{\circ}$. 


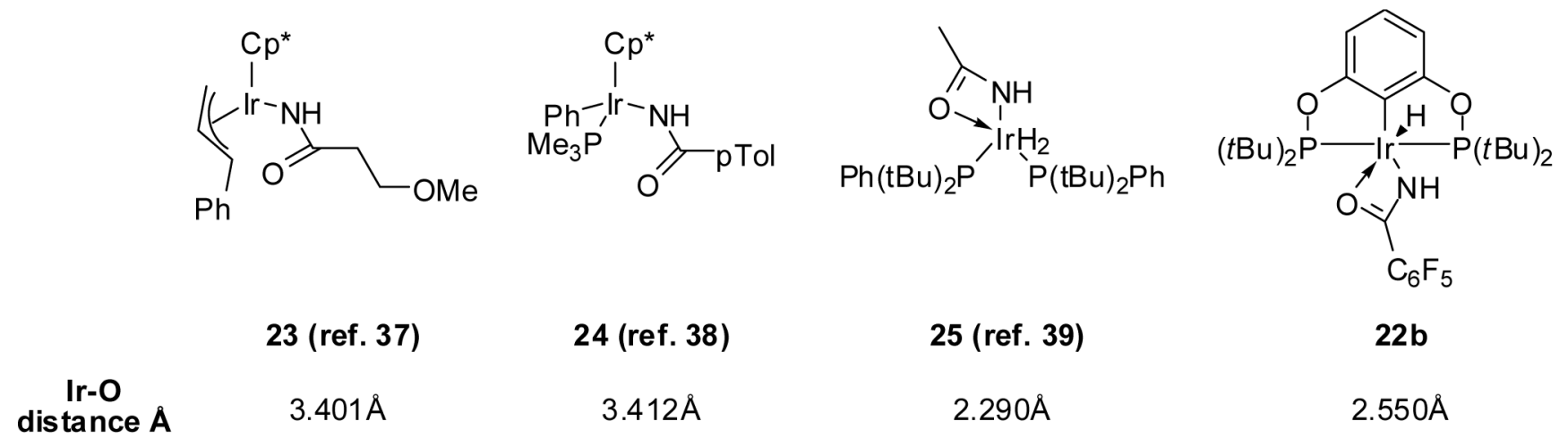

Figure 5.

Comparison of Ir-O bond distances with literature 


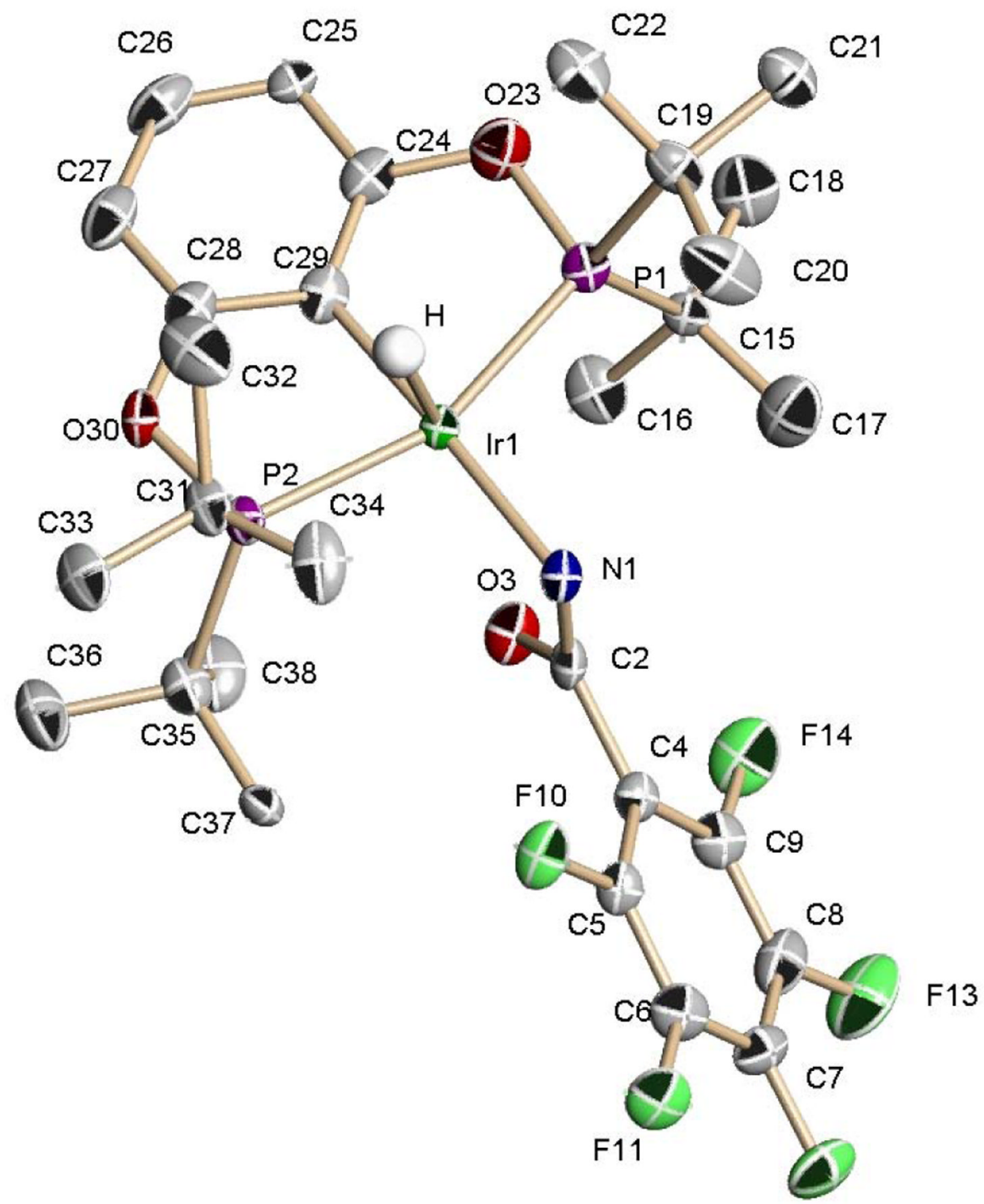

F12

Figure 6.

Crystal structure of (POCOP) $\operatorname{Ir}(\mathrm{H})\left(\mathrm{NH}(\mathrm{CO}) \mathrm{C}_{6} \mathrm{~F}_{5}\right)(\mathbf{2 2 b})$. Only the hydrogens on iridium are shown for clarity. Key bond distances $(\AA)$ and bond angles (degrees): $\operatorname{Ir}(1)-\mathrm{N}(1) 2.171 \AA$, N (1) - C(2) $1.279 \AA, \operatorname{Ir}(1)-\mathrm{C}(29) 2.034 \AA, \operatorname{Ir}(1)-\mathrm{P}(1) 2.412 \AA, \operatorname{Ir}(1)-\mathrm{P}(2) 2.359 \AA, \mathrm{H}(1)-\operatorname{Ir}(1)-$ $\mathrm{N}(1)-\mathrm{H}(2)-18.67^{\circ}, \mathrm{C}(29)-\operatorname{Ir}(1)-\mathrm{N}(1) 176.66^{\circ}, \mathrm{P}(1)-\operatorname{Ir}(1)-\mathrm{N}(1) 104.30^{\circ}, \mathrm{P}(2)-\operatorname{Ir}(1)-\mathrm{N}(1)$ $96.77^{\circ}, \operatorname{Ir}(1)-\mathrm{N}(1)-\mathrm{C}(2)-\mathrm{C}(4)-175.64^{\circ}$. 


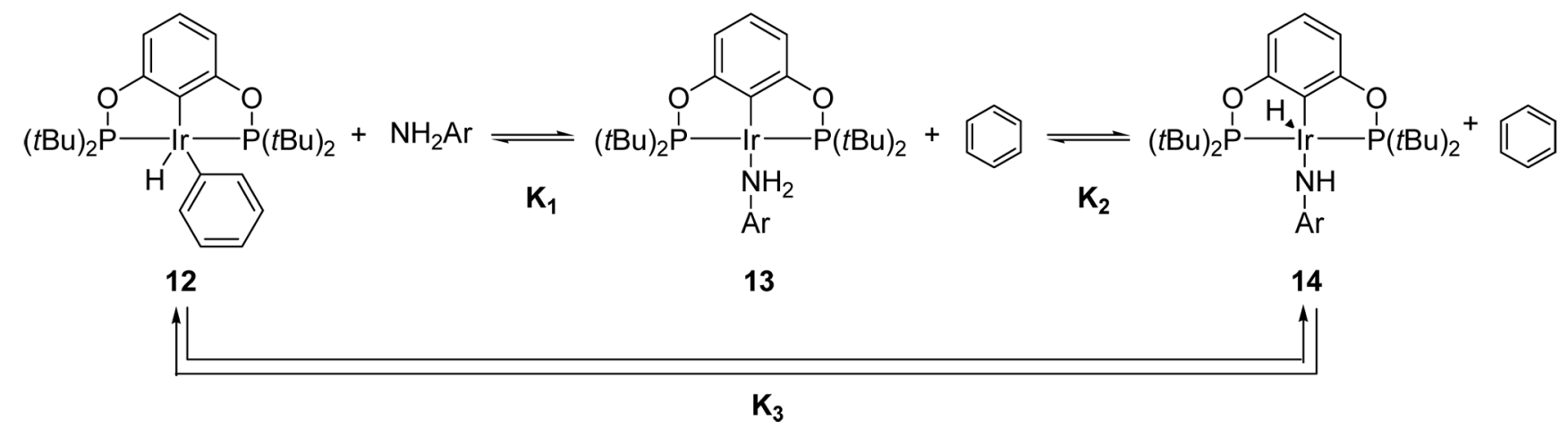

Scheme 1.

Equillibria between (POCOP) $\operatorname{Ir}(\mathrm{H})(\mathrm{Ph})(\mathbf{1 2}),(\mathrm{POCOP}) \operatorname{Ir}\left(\mathrm{NH}_{2} \mathrm{Ar}\right)(\mathbf{1 3})$, and $(\mathrm{POCOP}) \operatorname{Ir}(\mathrm{H})$ (NHAr) (14). 


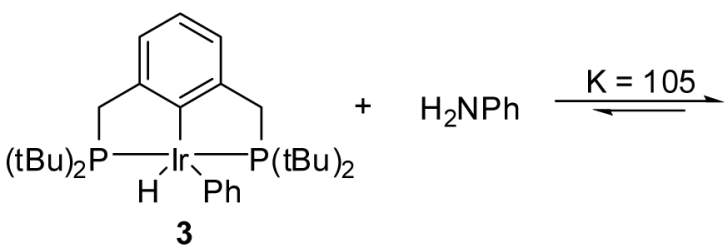

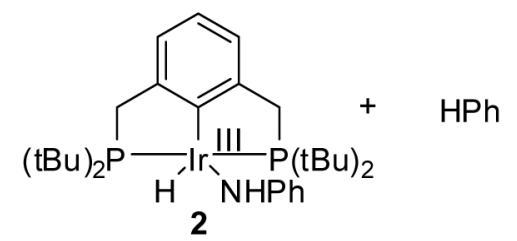

Only Ir(III) Adduct Observed

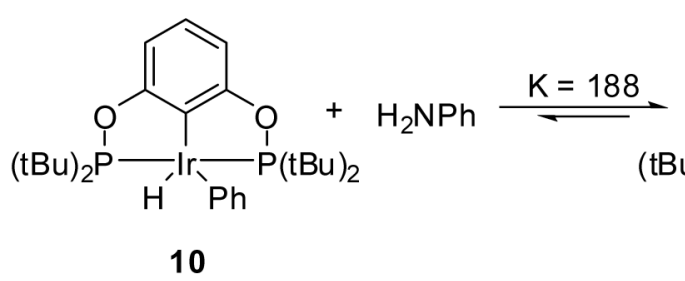

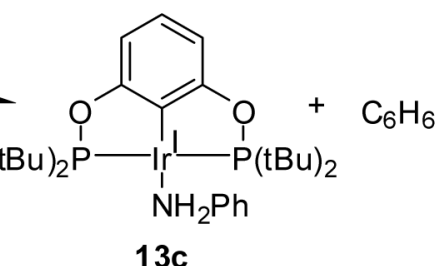<smiles></smiles>

$\operatorname{Ir}(\mathrm{I}) \sigma$ - Adduct Favored

Scheme 2.

Comparison of the reactions of $(\mathrm{PCP}) \operatorname{Ir}(\mathrm{H})(\mathrm{Ph})(\mathbf{3})$ and $(\mathrm{POCOP}) \operatorname{Ir}(\mathrm{H})(\mathrm{Ph})(\mathbf{1 0})$ with $\mathrm{NH}_{2} \mathrm{C}_{6} \mathrm{H}_{5}$. 


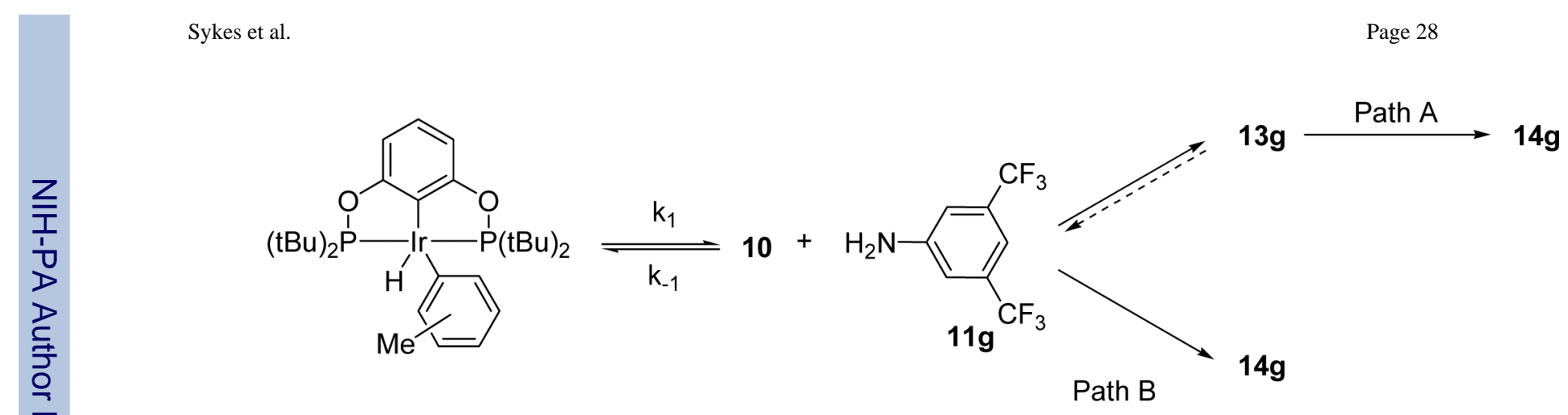

Scheme 3.

Possible mechanism for oxidative addition of $\mathbf{1 1 g}$. 
Case

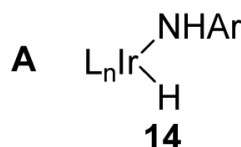

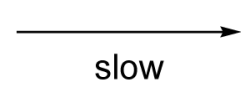

$\left[L_{n} \mid r\right]$

10

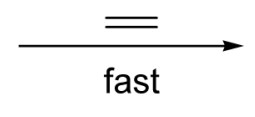

$\mathrm{L}_{\mathrm{n}} \mathrm{Ir}-\|$

18

B $\mathrm{L}_{\mathrm{n}} \mid \mathrm{r}_{\substack{14 \\ \mathbf{1 4}}}^{\mathrm{NHAr}}$

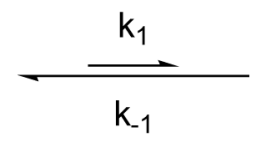

$\mathrm{L}_{n} \mathrm{Ir}-\mathrm{NH}_{13} \mathrm{Ar}$
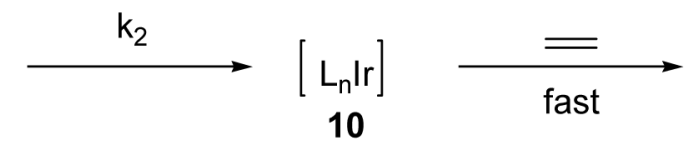

$\mathrm{L}_{\mathrm{n}} \mathrm{Ir}-\|$

18

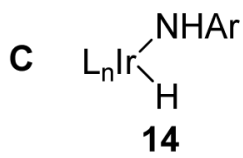

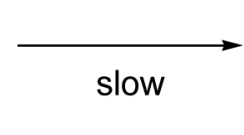

$\mathrm{L}_{\mathrm{n}} \mathrm{Ir}-\underset{13}{\mathrm{NH}} \mathrm{H}_{2} \mathrm{Ar}$

$+\quad=$

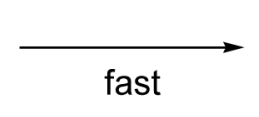

$\mathrm{L}_{\mathrm{n}} \mathrm{Ir}-\|$

Scheme 4. 


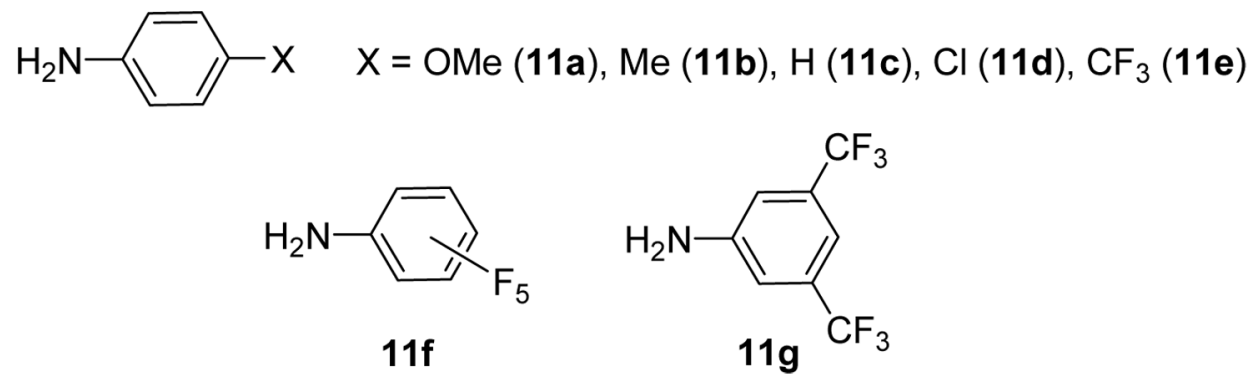

Chart 1.

Anilines of varying electron withdrawing/donating ability (11a-g) 
Table 1

Equilibrium Constants ${ }^{a}$ for $\mathbf{1 2}+\mathrm{NH}_{2} \mathrm{Ar} \rightleftharpoons \mathbf{1 3}+$ Benzene $\rightleftharpoons \mathbf{1 4}+$ Benzene at $25^{\circ} \mathrm{C}$.

\begin{tabular}{|c|c|c|c|}
\hline Aniline (11) & $\mathbf{K}_{1}$ & $\mathbf{K}_{2}$ & $K_{3}=\left(K_{1} K_{2}\right)$ \\
\hline $\mathbf{a}$ & 1130 & $b$ & ${ }_{-}^{b}$ \\
\hline $\mathbf{b}$ & 456 & $\overline{0.04}$ & $\overline{1} 8$ \\
\hline c & 188 & 0.1 & 19 \\
\hline d & 55 & 1 & 55 \\
\hline e & $c$ & $c$ & 260 \\
\hline f & ${ }_{-} c$ & ${ }_{-} c$ & 2190 \\
\hline g & ${ }_{-}^{-}$ & ${ }_{-} c$ & 2770 \\
\hline
\end{tabular}

$a_{\text {Equilibrium values are based on an average of 2-3 runs. }}$

${ }^{b}$ Concentration of 14a too low to detect

${ }^{c}$ Concentrations of $\mathbf{1 3 e}-\mathbf{g}$ too low to detect 
Table 2

Rates of reductive elimination of anilines (11e-g) from (POCOP) $\operatorname{Ir}(\mathrm{H})(\mathrm{NHAr})$ at $9{ }^{\circ} \mathrm{C}$ in toluene.

\begin{tabular}{|c|c|c|c|c|}
\hline Ir(III) Complex & Concentration of $\mathrm{C}_{2} \mathrm{H}_{4}, \mathrm{M}$ & $\mathrm{k}, \mathrm{s}^{-1} \times 10^{4}$ & $\underset{10^{4}}{\text { average }} \mathrm{k}, \mathrm{s}^{-1} \times$ & $\Delta \mathrm{G}^{\dagger} \mathrm{kcal} / \mathrm{mol}$ \\
\hline \multirow{2}{*}{$\mathbf{1 4 e}(0.022 \mathrm{M})$} & 0.087 & 4.0 & \multirow{2}{*}{4.2} & \multirow{2}{*}{20.8} \\
\hline & 0.28 & 4.4 & & \\
\hline \multirow{3}{*}{$14 \mathbf{f}(0.022 \mathrm{M})$} & 0.022 & 3.0 & \multirow{3}{*}{2.8} & \multirow{3}{*}{21.1} \\
\hline & 0.19 & 2.6 & & \\
\hline & 1.1 & 2.8 & & \\
\hline \multirow{3}{*}{$\mathbf{1 4 g}(0.036 \mathrm{M})$} & 0.18 & 0.42 & \multirow{3}{*}{0.45} & \multirow{3}{*}{22.1} \\
\hline & & & & \\
\hline & 0.34 & 0.47 & & \\
\hline
\end{tabular}

